\title{
Stimulatory actions of IGF-I are mediated by IGF-IR cross-talk with GPER and DDR1 in mesothelioma and lung cancer cells
}

\author{
Silvia Avino ${ }^{1, *}$, Paola De Marco ${ }^{1, *}$, Francesca Cirillo ${ }^{1}$, Maria Francesca Santolla ${ }^{1}$, \\ Ernestina Marianna De Francesco ${ }^{1}$, Maria Grazia Perri ${ }^{1}$, Damiano Rigiracciolo ${ }^{1}$, \\ Vincenza Dolce ${ }^{1}$, Antonino Belfiore ${ }^{2}$, Marcello Maggiolini ${ }^{1}$, Rosamaria Lappano ${ }^{1, * *}$ \\ and Adele Vivacqua ${ }^{1, * *}$ \\ ${ }^{1}$ Department of Pharmacy, Health and Nutritional Sciences, University of Calabria, Rende, Italy \\ 2 Endocrinology, Department of Health Sciences, University Magna Graecia of Catanzaro, Catanzaro, Italy \\ * These authors have contributed equally to this work \\ ** Joint senior Authors \\ Correspondence to: Marcello Maggiolini, email: marcellomaggiolini@yahoo.it \\ Keywords: DDR1, GPER, IGF-I, IGF-IR, mesothelioma, lung cancer, Pathology Section \\ Received: April 06, $2016 \quad$ Accepted: June 17, $2016 \quad$ Published: June 30, 2016
}

\section{ABSTRACT}

Insulin-like growth factor-I (IGF-I)/IGF-I receptor (IGF-IR) system has been largely involved in the pathogenesis and development of various tumors. We have previously demonstrated that IGF-IR cooperates with the G-protein estrogen receptor (GPER) and the collagen receptor discoidin domain 1 (DDR1) that are implicated in cancer progression. Here, we provide novel evidence regarding the molecular mechanisms through which IGF-I/IGF-IR signaling triggers a functional cross-talk with GPER and DDR1 in both mesothelioma and lung cancer cells. In particular, we show that IGF-I activates the transduction network mediated by IGF-IR leading to the up-regulation of GPER and its main target genes CTGF and EGR1 as well as the induction of DDR1 target genes like MATN-2, FBN-1, NOTCH 1 and HES-1. Of note, certain DDR1-mediated effects upon IGF-I stimulation required both IGF-IR and GPER as determined knocking-down the expression of these receptors. The aforementioned findings were nicely recapitulated in important biological outcomes like IGF-I promoted chemotaxis and migration of both mesothelioma and lung cancer cells. Overall, our data suggest that IGF-I/IGF-IR system triggers stimulatory actions through both GPER and DDR1 in aggressive tumors as mesothelioma and lung tumors. Hence, this novel signaling pathway may represent a further target in setting innovative anticancer strategies.

\section{INTRODUCTION}

Lung cancer is the most frequent cause of cancer incidence and mortality worldwide at least in part due to the increasing number of risk factors in diverse developing countries [1-2]. To date, smoking has been considered the main etiologic factor for lung cancer [34], however, several environmental contaminants like asbestos, arsenic, cadmium, nickel and silica, play an important role toward the development of this neoplasia [5]. Among the aforementioned environmental pollutants, asbestos has been particularly acknowledged as prompting factor in malignant mesothelioma (MM), which is an aggressive cancer that arises from mesothelial cells lining lung, pleura or peritoneum [6-7]. Chronic inflammatory processes caused by the deposition of asbestos fibers and the subsequent release of cytokines and growth factors by macrophages and mesothelial cells have been shown to play an active role toward the development of both pleural MM and lung cancer [7-8].

In this vein, the IGF system, the complex system involving the insulin-like growth factors (IGFs) and related receptors as well as IGF-binding proteins, has been established as an important regulator of tumor initiation 
and progression in several malignancies, including pleural MM and lung cancer [9-13]. In particular, the IGF-I receptor (IGF-IR), which is often overexpressed in diverse cancer cell types, affects tumor development, progression and resistance to therapies [11, 14-16]. Moreover, a dysregulated IGF system has been shown to be implicated in various chronic diseases, such as pulmonary fibrosis [17-18].

An increasing body of data has demonstrated that the biological responses mediated by IGF-I involve functional interactions of IGF-IR with diverse signal molecules belonging to other members of the receptor tyrosine kinase (RTK) family [19-20]. In this context, we recently discovered a novel functional cross-talk between IGF-IR and the collagen receptor discoidin domain receptor 1 (DDR1), a molecule also overexpressed in diverse malignancies, including lung carcinomas, and implicated in cancer progression [21]. Interestingly, this cross-talk occurs also independently of the collagen binding actions of DDR1 and, in human breast cancer cells, amplifies the stimulatory biological effects of IGF-I toward proliferation, migration and colony formation. Moreover, through a signaling pathway involving Akt/ miR-199a-5p, IGF-I is able to upregulate DDR1 [12, 22].

In addition to RTKs, IGF-IR interacts with other important signaling molecules like $G$ protein-coupled receptors (GPCRs) [19, 23]. These functional interactions have also important implications in the development and progression of diverse types of tumors [23-24]. In particular, we found that IGF-IR activation engages the $\mathrm{G}$ protein estrogen receptor (GPER/GPR30)-mediated signaling toward the stimulation of proliferation and migration of different cancer cell types [25-26]. Interestingly, high expression levels of GPER were detected in lung cancer cells and involved in growth stimulatory effects [24, 27-28]. To date, other signaling molecules have been implicated in the development of MM including the estrogen receptor (ER) $\beta$ that may act as a tumor suppressor [29-30]. Therefore, the multifaceted mechanisms and the transduction network of factors involved in the progression of the aforementioned malignancies remain to be fully understood.

In this study, we found that mesothelioma and lung cancer cells show a new complex functional crosstalk involving IGF-IR, GPER and DDR1, which affects gene expression and biological effects in response to IGF-I. Our data, therefore, further extend the molecular mechanisms by which IGF-I may affect tumor progression in mesothelioma and lung cancer, hence providing novel targets in the aforementioned aggressive malignancies.

\section{RESULTS}

\section{IGF-I stimulates GPER expression through IGF- IR/ERK/p-38 transduction signaling}

On the basis of previous studies showing that IGF-I triggers stimulatory effects in malignant mesothelioma as well as in lung cancer cells [31-32], we began our study evaluating the transduction signaling activated by IGF-I in IST-MES1 mesothelioma and A549 lung cancer cells, which were used as model system. First, we determined that in both cell types IGF-I induces the phosphorylation of IGF-IR (Figure 1A) and both ERK (Figure 1B) and p-38 (Figure 1C). As expected, these responses were no longer observed after IGF-IR silencing (Figure 1 A-1E). The activation of ERK triggered by IGF-I was abolished in the presence of the IGF-IR inhibitor AG and the MEK inhibitor PD, but it still persisted using the p-38 inhibitor SB (Figure 1F). The phosphorylation of p-38 was prevented by $\mathrm{AG}$ and $\mathrm{SB}$, but not in the presence of PD (Figure 1G). In addition, we assessed that the phosphorylation of IGF-IR induced by IGF-I is inhibited exclusively by $\mathrm{AG}$, but not in the presence of PD and SB (data not shown), then suggesting that the activation of both ERK and p-38 relies directly on IGF-IR phosphorylation upon IGF-I exposure. On the basis of our previous data showing that IGF-I signaling cooperates with several GPCR family members, including GPER, toward cancer progression $[19,25]$, we evaluated whether IGF-I regulates GPER expression in IST-MES1 and A549 cells. In this regard, time-course experiments demonstrated that IGF-I up-regulates GPER at both mRNA (Figure 2A) and protein levels (Figure 2B). Moreover, we ascertained that these responses to IGF-I occurred through IGF-IR, as the induction of GPER mRNA (data not shown) and protein levels (Figure 2C-2E) was abolished by knocking-down IGF-IR expression. Recapitulating the aforementioned findings, the transactivation of the GPER promoter by IGF-I was prevented by IGF-IR silencing (Figure 2F), and the IGF-I induced GPER protein up-regulation was abrogated in the presence of $A G, P D$ and $S B$ (Figure 2G). Taken together, these results indicate that the IGF-I/IGFIR transduction pathway stimulates GPER expression through ERK and p-38 signaling. In order to further investigate this functional cross-talk between IGF-IR and GPER, we performed co-immunoprecipitation studies determining that IGF-I triggers also a direct interaction between these receptors in both IST-MES1 and A549 cells upon either $1 \mathrm{~h}$ (data not shown) or $8 \mathrm{~h}$ treatment with IGF-I (Figure 2H-2I), thus suggesting that the interaction between IGF-IR and GPER may occur without a newly protein expression of GPER. 
$\mathbf{A}$
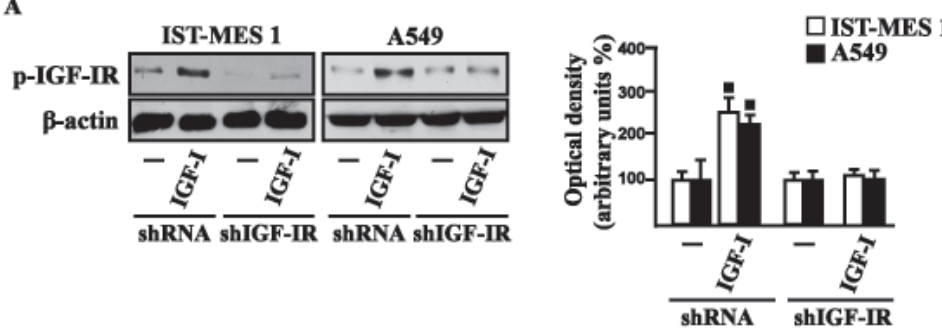

B
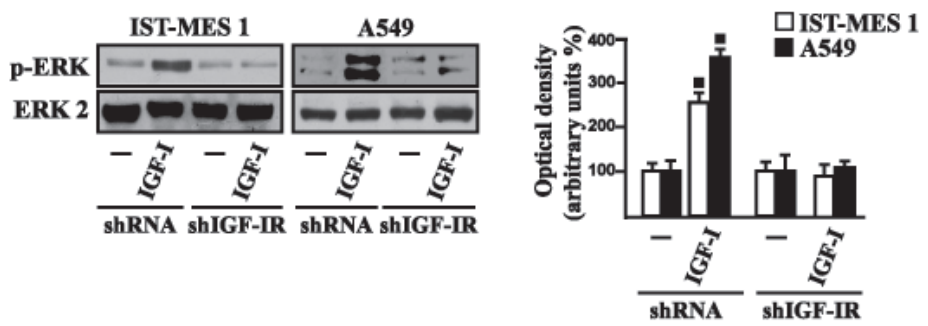

C
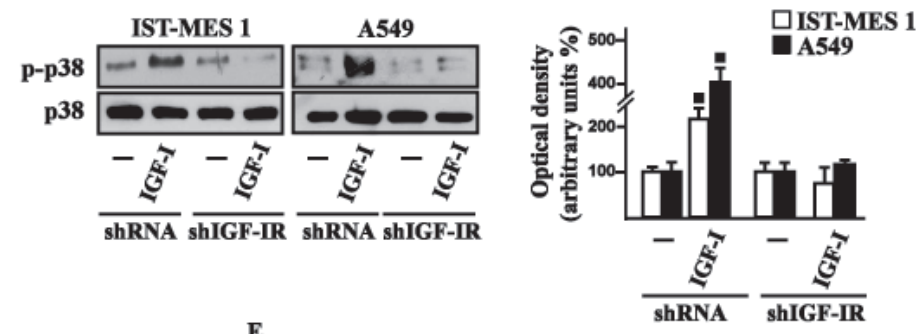

D

$\mathbf{E}$

IST-MES 1
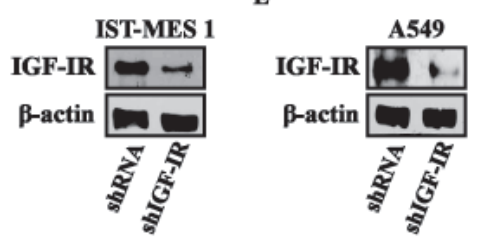

$\mathbf{F}$
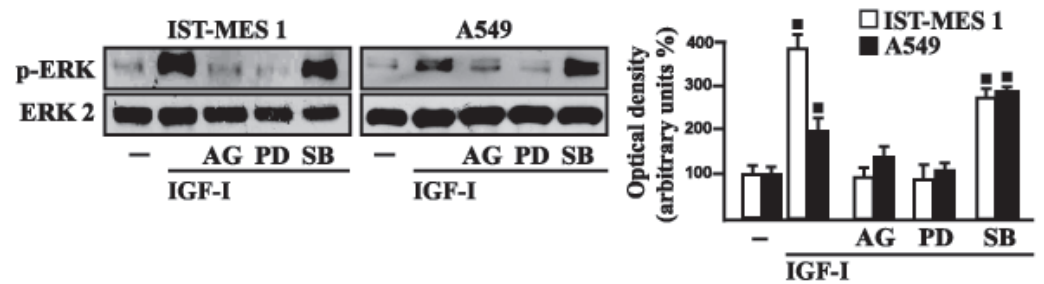

G

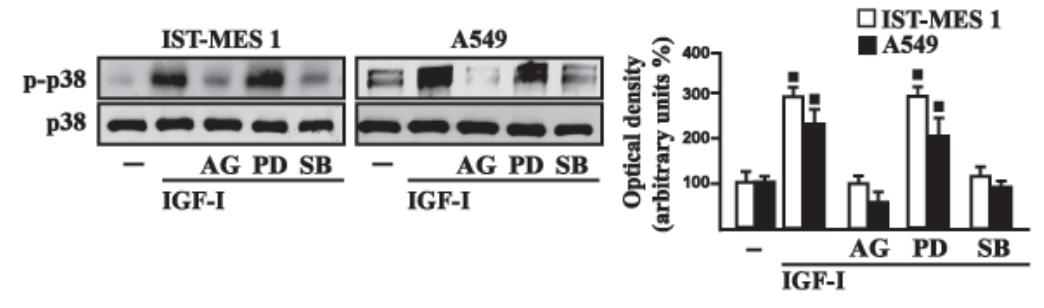

Figure 1: Rapid activation of transduction signaling by IGF-I in IST-MES 1 and A549 cells. IGF-IR A., ERK B. and p-38 C. phosphorylation in cells transfected for $24 \mathrm{~h}$ with shRNA or shIGF-IR treated with vehicle (-) or $100 \mathrm{ng} / \mathrm{ml} \mathrm{IGF-I} \mathrm{for} 15 \mathrm{~min}$. D.-E. Efficacy of IGF-IR silencing. ERK F. and p-38 G. activation in cells treated for $15 \mathrm{~min}$ with vehicle (-) or $100 \mathrm{ng} / \mathrm{ml} \mathrm{IGF-I} \mathrm{alone} \mathrm{and} \mathrm{in} \mathrm{combination}$ with either $1 \mu \mathrm{M}$ IGF-IR inhibitor tyrphostin AG1024 (AG), or $1 \mu \mathrm{M}$ MEK inhibitor PD98059 (PD) or $1 \mu \mathrm{M}$ p38 inhibitor SB202190 (SB). Side panels show densitometric analysis of the blots normalized to $\beta$-actin, ERK2 and p38 that served as loading controls respectively for pIGF-IR, pERK and p-p38. Data shown are the mean \pm SD of three independent experiments. ( $\mathbf{-}) p<0.05$ for cells receiving vehicle (-) versus treatments. 
A

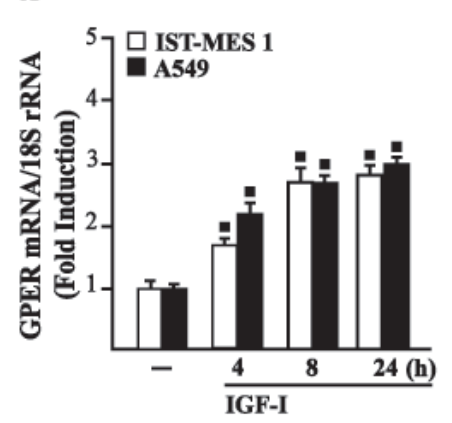

B

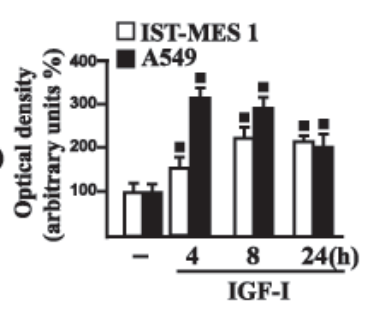

C
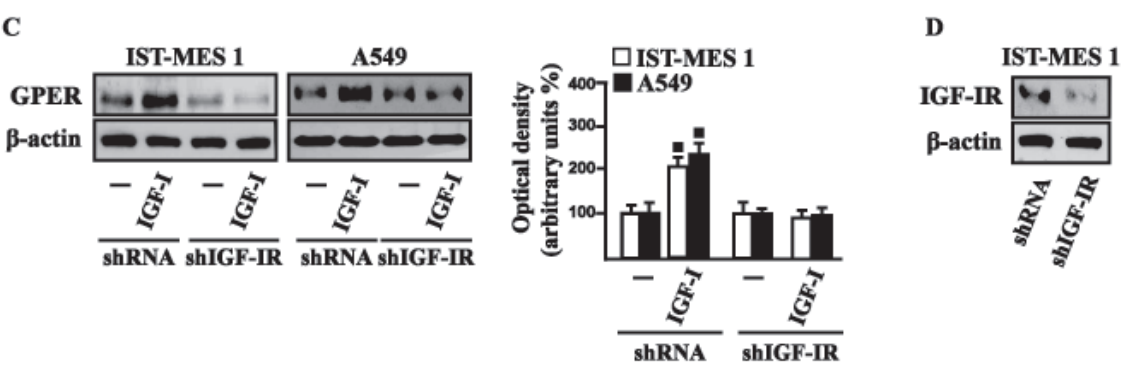

$\mathbf{E}$

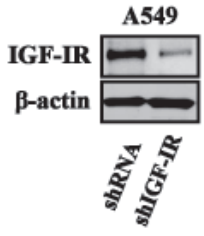

$\mathbf{F}$

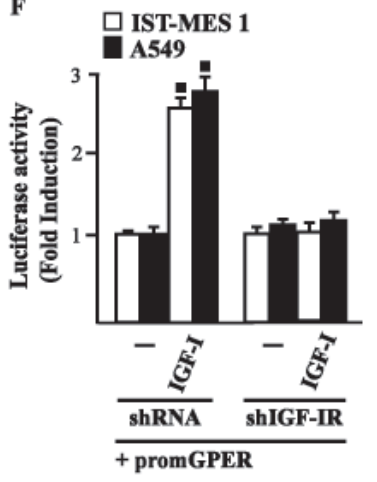

G

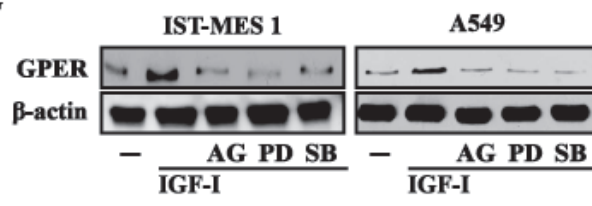

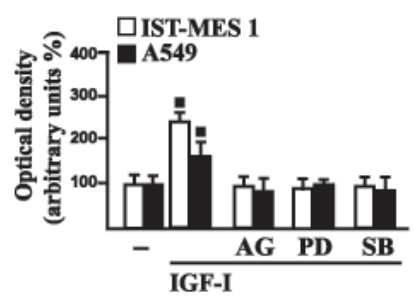

$\mathbf{H}$

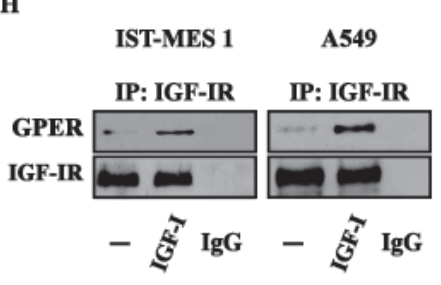

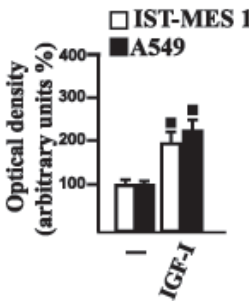

I

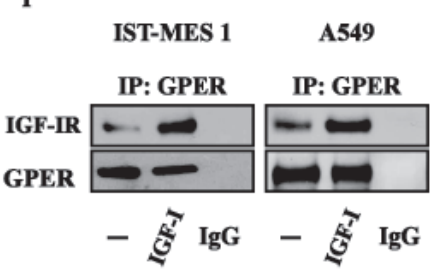

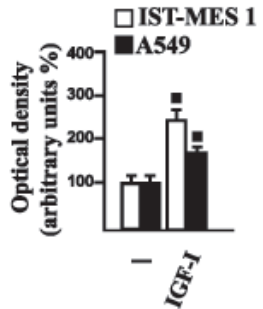

Figure 2: IGF-I up-regulates GPER expression in IST-MES 1 and A549 cells. A. mRNA expression of GPER in cells treated with either vehicle (-) or $100 \mathrm{ng} / \mathrm{ml} \mathrm{IGF-I,} \mathrm{as} \mathrm{evaluated} \mathrm{by} \mathrm{real-time} \mathrm{PCR.} \mathrm{Results} \mathrm{obtained} \mathrm{from} \mathrm{experiments} \mathrm{performed} \mathrm{in} \mathrm{triplicate} \mathrm{were}$ normalized for $18 \mathrm{~S}$ expression and shown as fold change of RNA expression compared to cells treated with vehicle. B. GPER protein levels

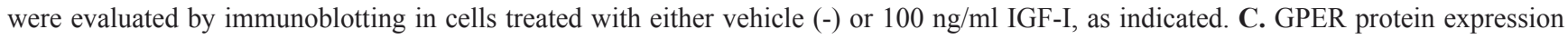
in cells transfected for $24 \mathrm{~h}$ with either shRNA or shIGF-IR and then treated for $8 \mathrm{~h}$ with vehicle (-) or $100 \mathrm{ng} / \mathrm{ml} \mathrm{IGF-I.} \mathrm{D.-E.} \mathrm{Efficacy}$ of IGF-IR silencing. F. Cells were transfected for $24 \mathrm{~h}$ with shRNA or shIGF-IR together with the GPER promoter construct. Then, cells were treated for $18 \mathrm{~h}$ with vehicle (-) or $100 \mathrm{ng} / \mathrm{ml} \mathrm{IGF-I.} \mathrm{The} \mathrm{luciferase} \mathrm{activities} \mathrm{were} \mathrm{normalized} \mathrm{to} \mathrm{the} \mathrm{internal} \mathrm{transfection} \mathrm{control,} \mathrm{and}$ values of cells receiving vehicle (-) were set as one fold induction upon which the activity induced by treatments was calculated. G. GPER protein levels in cells treated for $8 \mathrm{~h}$ with vehicle (-) or $100 \mathrm{ng} / \mathrm{ml}$ IGF-I alone or in combination with $1 \mu \mathrm{M}$ IGF-IR inhibitor tyrphostin AG1024 (AG), $1 \mu \mathrm{M}$ MEK inhibitor PD98059 (PD) and $1 \mu \mathrm{M}$ p38 inhibitor SB202190 (SB). Side panels show densitometric analysis of the blots normalized to $\beta$-actin. H.-I. Co-immunoprecipitation studies performed in cells treated for $8 \mathrm{~h}$ with vehicle (-) or $100 \mathrm{ng} / \mathrm{ml} \mathrm{IGF}-\mathrm{I}$, as indicated. In control samples, non-specific IgG was used instead of the primary antibody. H. Side panel show densitometric analysis of the blot normalized to IGF-IR. I. Side panel show densitometric analysis of the blot normalized to GPER. Data shown are the mean \pm SD of three independent experiments. ( $\mathbf{-}) p<0.05$ for cells receiving vehicle (-) versus treatments. 
IGF-I triggers the expression of GPER target genes

In our previous study [33] we established that GPER mediates a specific gene signature, therefore, we evaluated whether, in IST-MES1 and A549 cells, IGF-I is able to affect the expression of certain GPER target genes like CTGF and EGR1, which have been involved in fibrotic responses in mesothelioma and lung cancer cells [3436]. Indeed, in time-course experiments we found that
$\mathbf{A}$

IST-MES 1

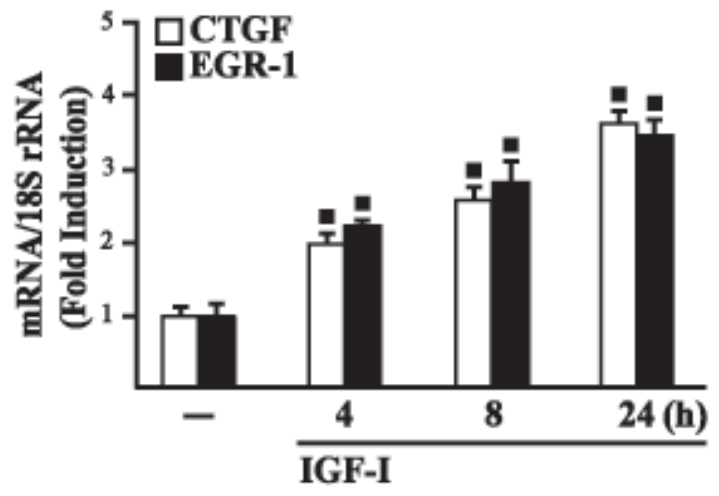

C

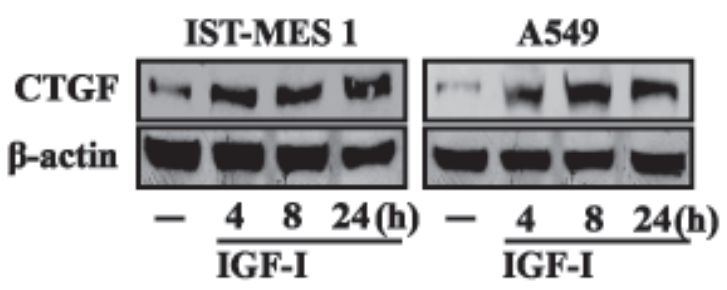

B

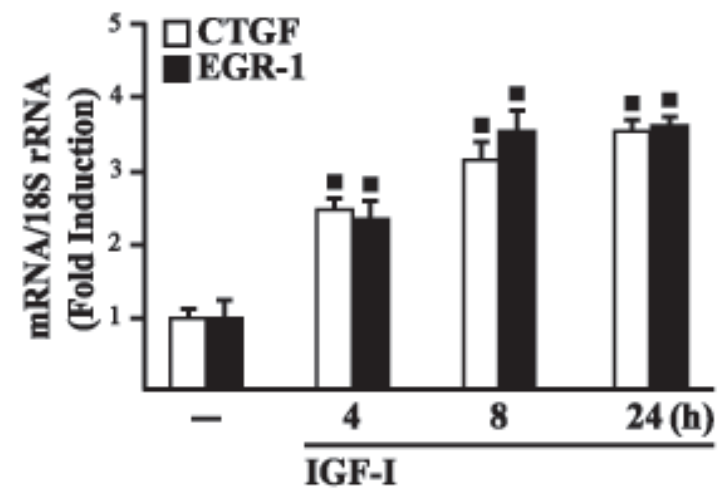

D
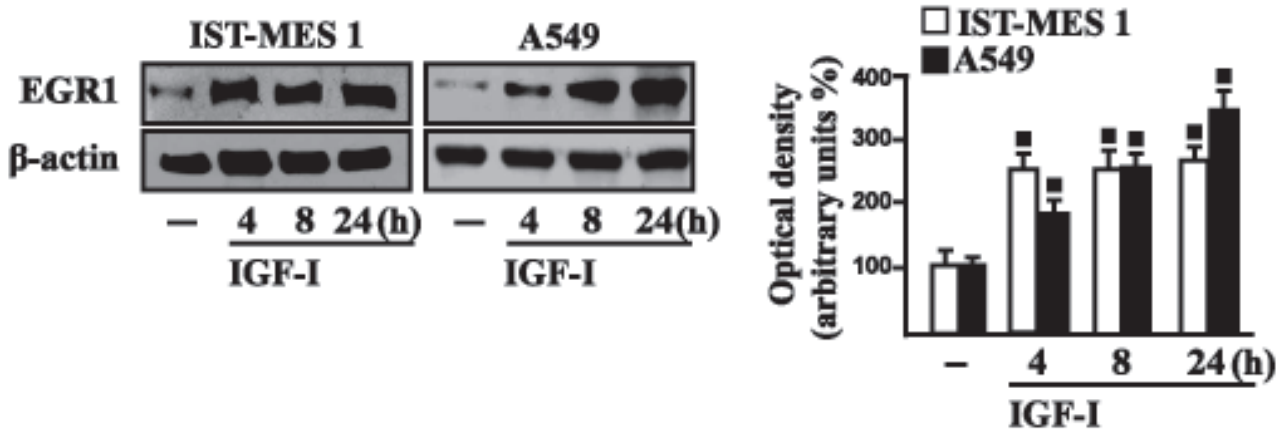

Figure 3: IGF-I up-regulates CTGF and EGR1 expression in IST-MES 1 and A549 cells. (A-B) mRNA expression of CTGF and EGR1 in cells treated with either vehicle (-) or $100 \mathrm{ng} / \mathrm{ml}$ IGF-I, as evaluated by real-time PCR. Results obtained from experiments performed in triplicate were normalized for 18S expression and shown as fold change of RNA expression compared to cells treated with vehicle. CTGF C. and EGR1 D. protein levels were evaluated by immunoblotting in cells treated with vehicle (-) or $100 \mathrm{ng} / \mathrm{ml}$ IGF-I, as indicated. Side panels show densitometric analysis of the blots normalized to $\beta$-actin and each data point represents the mean $\pm \mathrm{SD}$ of three independent experiments. (-) $p<0.05$ for cells receiving vehicle (-) versus treatments. 
IGF-I increases the mRNA (Figure 3A-3B) and protein levels (Figure 3C-3D) of both CTGF and EGR1. Next, we determined that this action of IGF-I involves not only the IGF-IR but also GPER, as the silencing of each of these receptors prevented gene changes (Figure 4A$4 \mathrm{H})$. In accordance with these observations, the IGF-I transactivation of CTGF (Figure 4I) and EGR1 (Figure $4 \mathrm{~J})$ promoters required both IGF-IR and GPER, as demonstrated by knocking down the expression of these receptors. As c-fos plays a main role in the up-regulation of GPER target genes [33, 37], we next determined that the promoter transactivation of both CTGF and EGR1 is abrogated by co-transfecting a dominant-negative form of c-fos (DN/c-fos) in IST-MES1 and A549 cells (Figure 4K). Collectively, these findings provide novel mechanisms through which IGF-I/IGF-IR transduction signaling regulates GPER target genes like CTGF and EGR1 in mesothelioma and lung cancer cells.

\section{IGF-IR and GPER are both involved in IGF-I regulation of DDR1 target genes}

Considering that in diverse model systems IGF-I stimulates the synthesis of collagen [38-40], we next established that IGF-I regulates in both IST-MES1 and A549 cells the mRNA expression of COL1A1 (Figure 5A) that encodes the major component of type I collagen [41]. We previously reported that IGF-IR functionally interacts with DDR1, which is activated by various collagen types including type I collagen. Therefore, we first ascertained that, in both IST-MES1 and A549 cells, several DDR1 target genes such as matrilin-2 (MATN-2), fibrillin-1 (FBN-1), NOTCH 1 and HES-1, are induced by the DDR1 agonist COL1 (Figure 5B-5C) and abrogated by the DDR1 inhibitor (DDR1 IN) (Figure 5D-5E). Then, we assessed that these DDR1 target genes are also stimulated by IGF-I (Figure 6A-6B) and that this response was inhibited by DDR1 IN (Figure 6C-6D) as well as by silencing IGF-IR (Figure 6E-6F) or GPER (Figure 6G-6H). In accordance with these findings, we determined that the $\mathrm{NOTCH} 1$ protein induction by COL1 and IGF-I is prevented in the presence of the DDR1 IN in IST-MES1 and A549 cells (Figure 7). Accordingly, IGF-I was not able to trigger NOTCH 1 protein expression when IGF-IR (Figure 8A8C) or GPER (Figure 8D-8F) were silenced. Altogether, these results indicate that, in both mesothelioma and lung cancer cells, IGF-I may up-regulate DDR1 target genes, and this action involves not only IGF-IR but also a crosstalk with GPER.

\section{DDR1, IGF-IR and GPER contribute to the chemotaxis and migration of mesothelioma and lung cancer cells}

Previous studies have reported that IGF-I stimulates chemotactic and chemokinetic motility in mesothelioma cells [32]. Moreover, DDR1 also plays an important role in promoting cell-cell interactions and cell migration in various cell contexts [42-45]. Further extending these data, in IST-MES1 cells, we found that both IGF-I and COL1 induce chemotactic motility, which requires DDR1, as these responses were abolished by DDR1 IN (Videos 1-6). Moreover, we ascertained that the chemotactic motility induced by IGF-I requires also IGFIR and GPER as the aforementioned effect was prevented silencing the expression of these receptors (Videos 7-12). Similar findings occurred in A549 cells (data not shown). Likewise, we determined that IST-MES1 and A549 cell migration induced by both IGF-I and COL1 is abolished using DDR1 IN (Figure 9A), whereas the silencing of IGF-IR or GPER abolished cell migration triggered by IGF-I, as determined by Boyden chamber assay (Figure 9B). Collectively, our data indicate novel cross-talk and biological functions exerted by IGF-I toward tumor progression.

\section{DISCUSSION}

In the present study we provide novel evidence regarding the molecular mechanisms by which IGF-I triggers biological responses in mesothelioma and lung cancer cells. In particular, we show a complex functional cooperation involving IGF-IR, GPER and DDR1 through which IGF-I up-regulates first the expression of COL1A1 and certain DDR1 target genes, thereafter stimulating cancer cell motility and chemotactic response (Figure 10).

Lung cancer is a highly heterogeneous tumor that can arise in different sites of the bronchial tree [1-2]. The incidence of lung cancer depends on toxic effects of inhaled substances such as tobacco, asbestos, arsenic, cadmium, nickel and silica [46]. The environmental pollutant asbestos is also considered the main cause of the insurgence of malignant mesothelioma (MM), which is a rare and aggressive tumor that springs from mesothelial cells lining lung, pleura or peritoneum [5-7, 47-48]. The deposition of asbestos fibers has been also related to chronic inflammatory processes as well as to pulmonary fibrosis, which in turn may create a favorable environment for the development of lung and pleura malignancies [6, 49]. As it concerns the multifaceted mechanisms and factors involved in pulmonary fibrosis and neoplasia, an increased expression and activation of DDR1 have been reported [50-53]. To date, DDR1 has been shown to play an important role in cancer progression by regulating the interactions of tumor cells with the surrounding 
A

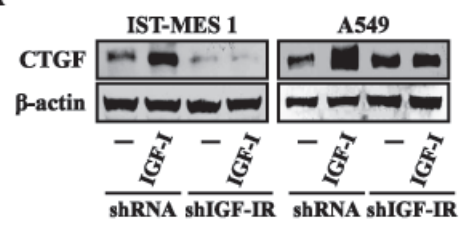

B

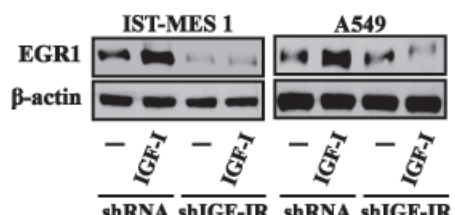

ShRA shIGF-IR shRNA shIGF-IR
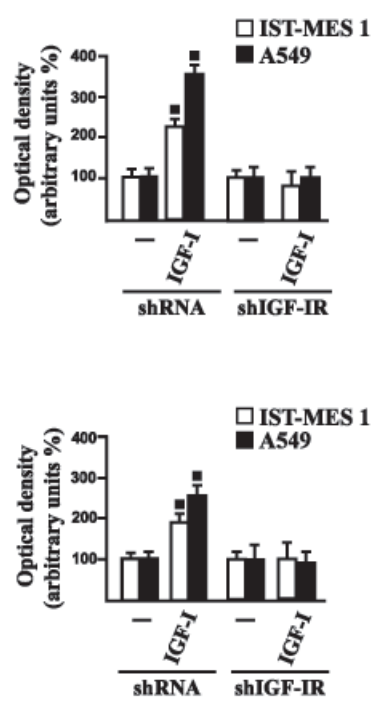

C

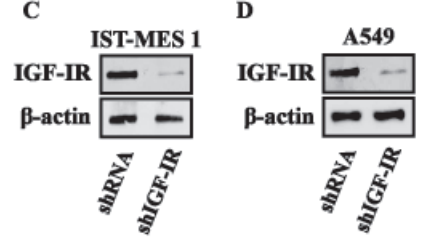

$\mathbf{E}$

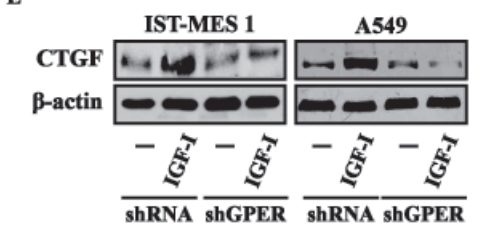

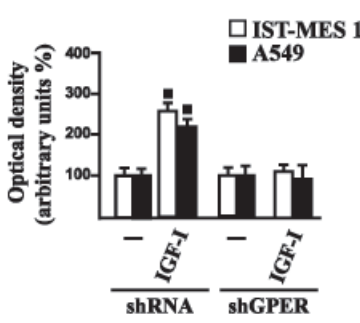

F
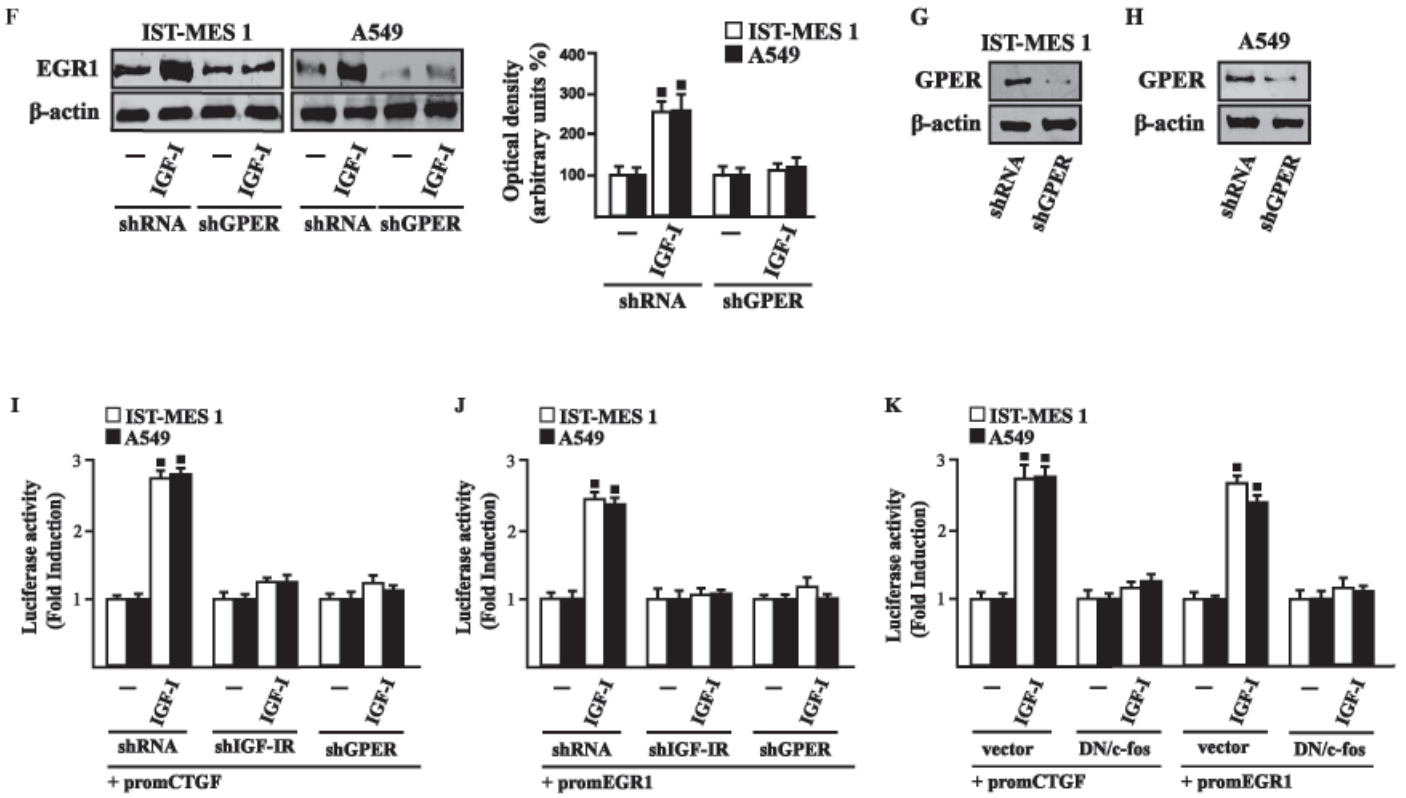

Figure 4: IGF-IR and GPER mediate CTGF and EGR1 stimulation by IGF-I in IST-MES 1 and A549 cells. A.-F. CTGF and EGR1 protein levels in cells transfected for $24 \mathrm{~h}$ with shRNA, shIGF-IR or shGPER and then treated for $8 \mathrm{~h}$ with either vehicle (-) or $100 \mathrm{ng} / \mathrm{ml}$ IGF-I. Efficacy of IGF-IR C.-D. and GPER G.-H. silencing. Side panels show densitometric analysis of the blots normalized to $\beta$-actin. I.-J. Cells were transfected for $24 \mathrm{~h}$ with shRNA, shIGF-IR or shGPER together with the CTGF or EGR1 promoter construct. Then, cells were treated for $18 \mathrm{~h}$ with vehicle (-) or $100 \mathrm{ng} / \mathrm{ml}$ IGF-I. K. Cells were transfected for $24 \mathrm{~h}$ with a dominant negative form of c-fos (DN/c-fos) together with the CTGF or EGR1 promoter construct. Then, cells were treated for $18 \mathrm{~h}$ with vehicle (-) or $100 \mathrm{ng} / \mathrm{ml}$ IGF-I. The luciferase activities were normalized to the internal transfection control, and values of cells receiving vehicle (-) were set as one fold induction upon which the activity induced by treatments was calculated. Data shown are the mean $\pm \mathrm{SD}$ of three independent experiments. (匹) $p<0.05$ for cells receiving vehicle (-) versus treatments. 
$\mathbf{A}$

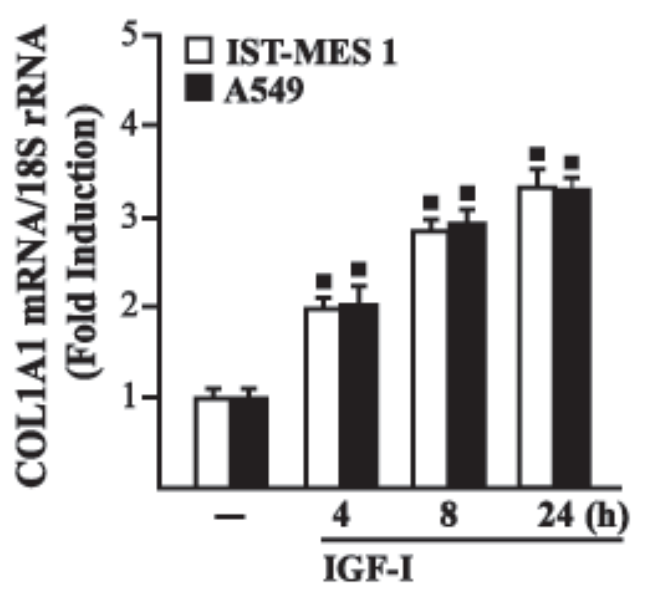

B

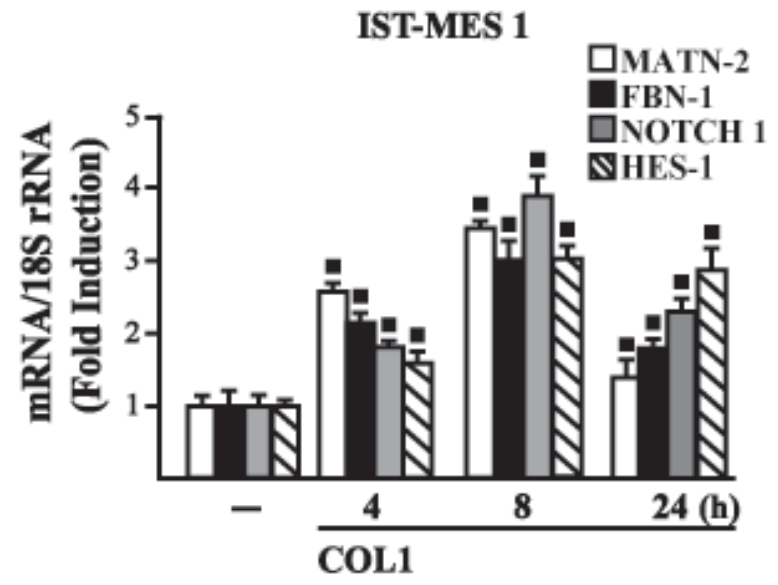

D

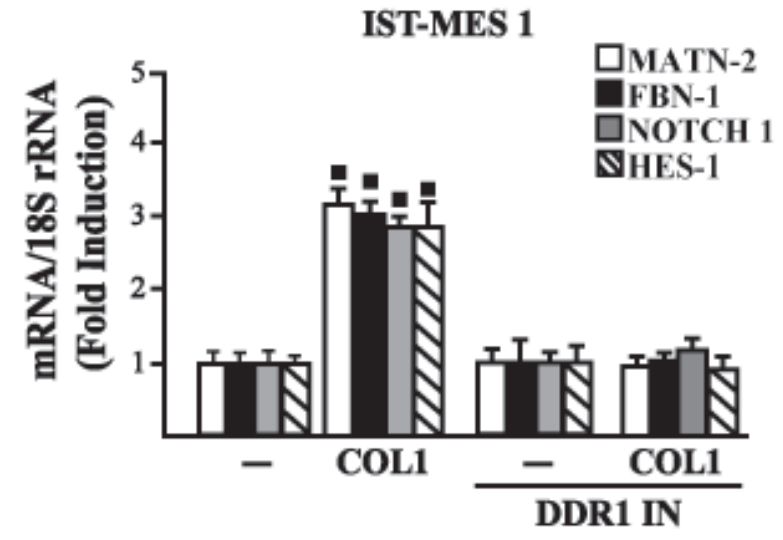

C

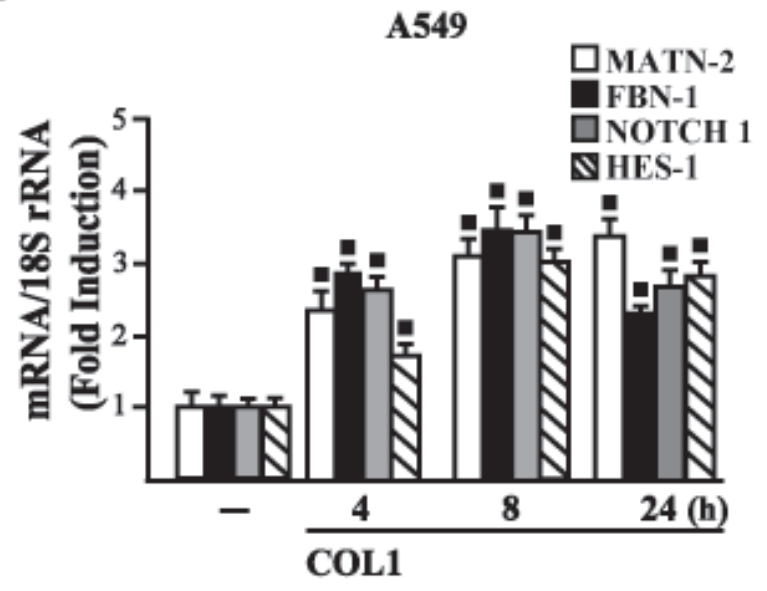

E

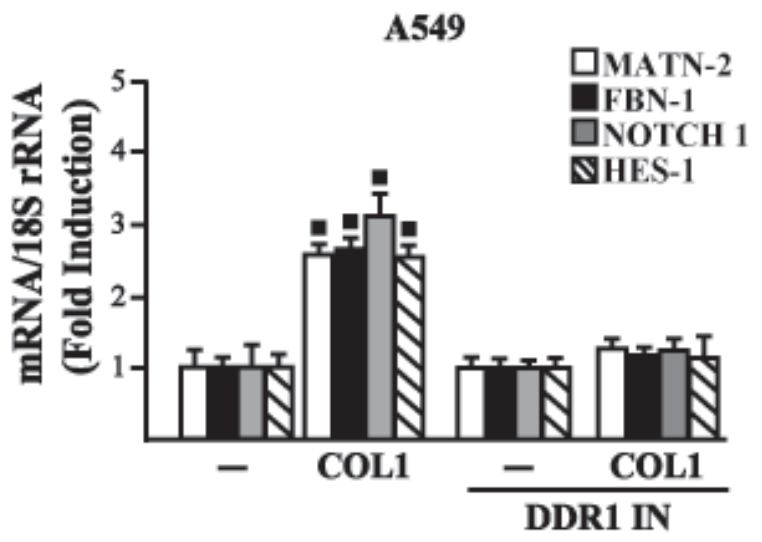

Figure 5: A. mRNA expression of COL1A1 in IST-MES 1 and A549 cells treated with vehicle (-) or $100 \mathrm{ng} / \mathrm{ml}$ IGF-I, as evaluated by real-time PCR. mRNA expression of MATN-2, FBN-1, NOTCH 1 and HES-1 in IST-MES 1 B., D. and A549 C., E. cells treated with vehicle (-) or $10 \mu \mathrm{g} / \mathrm{ml}$ COL1 alone or in combination with $1 \mu \mathrm{M}$ DDR1 inhibitor (DDR1 IN), as indicated. Results obtained from experiments performed in triplicate were normalized for $18 \mathrm{~S}$ expression and shown as fold change of RNA expression compared to cells treated with vehicle. (-) $p<0.05$ for cells receiving vehicle (-) versus treatments. 
$\mathbf{A}$

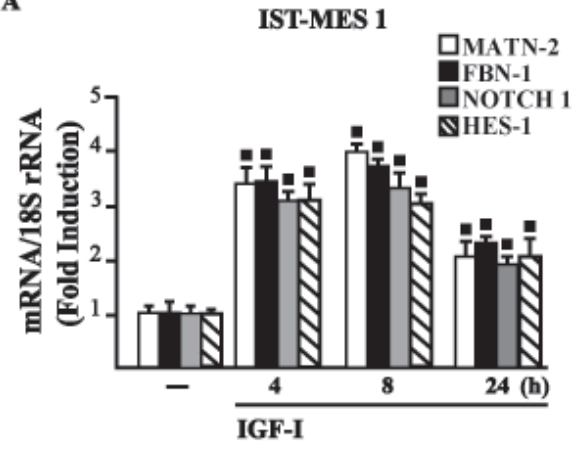

$\mathbf{C}$

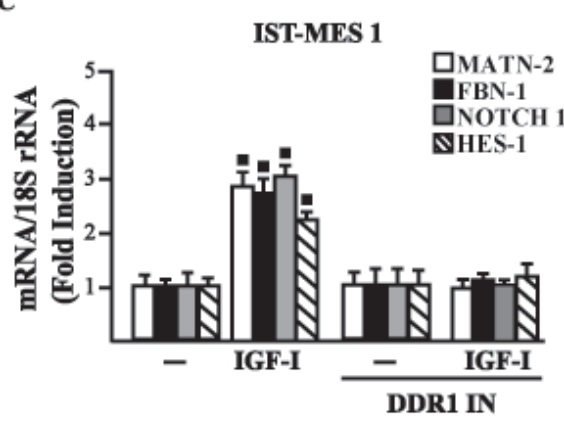

$\mathbf{E}$

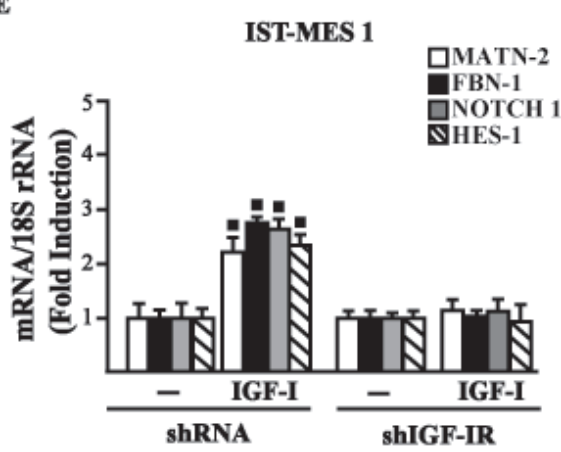

G

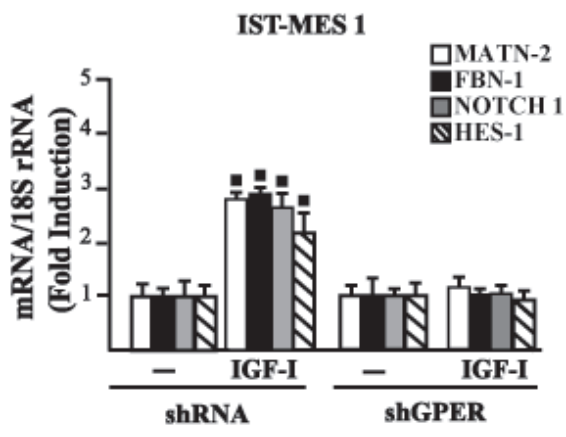

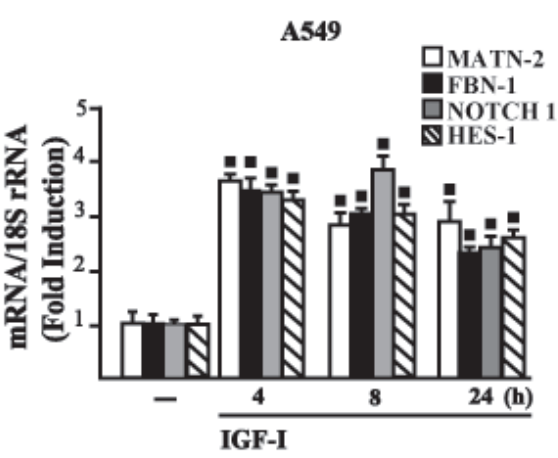

D
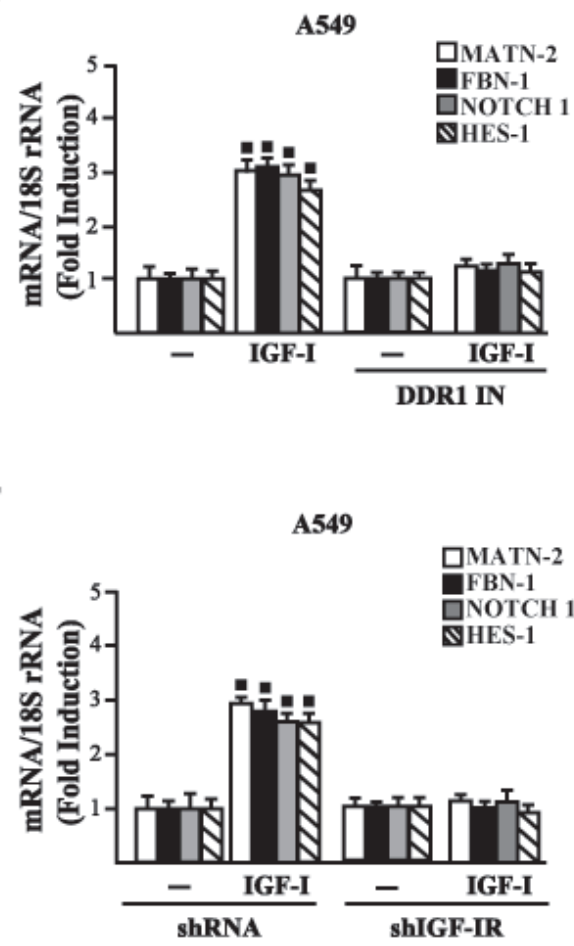

$\mathbf{H}$

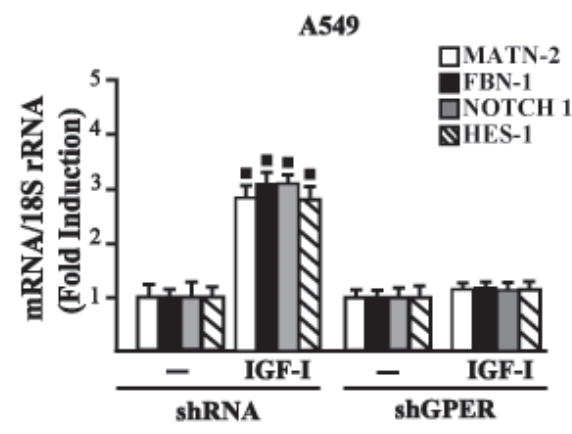

Figure 6: IGF-IR and GPER mediate the IGF-I induced up-regulation of COL1A1/DDR1 target genes in IST-MES 1 and A549 cells. A.-D. mRNA expression of MATN-2, FBN-1, NOTCH 1 and HES-1 in cells treated with vehicle (-) or $100 \mathrm{ng} / \mathrm{ml}$ IGF-I alone or in combination with $1 \mu \mathrm{M}$ DDR1 inhibitor (DDR1 IN), as indicated. E.-H. mRNA expression of MATN-2, FBN-1, NOTCH 1 and HES-1 in cells transfected for $24 \mathrm{~h}$ with shRNA, shIGF-IR or shGPER and then treated for $8 \mathrm{~h}$ with vehicle (-) or $100 \mathrm{ng} / \mathrm{ml} \mathrm{IGF-I.} \mathrm{Results}$ obtained from experiments performed in triplicate were normalized for $18 \mathrm{~S}$ expression and shown as fold change of RNA expression compared to cells treated with vehicle. ( $\mathbf{\square}) p<0.05$ for cells receiving vehicle (-) versus treatments. 
collagen matrix, therefore leading to pro-migratory and pro-invasive responses [21]. Furthermore, collagen activated DDR1 triggers diverse pro-survival pathways toward anti-apoptotic, proliferative and aggressive features in cancer cells [21]. In this regard, it should be noted that several types of collagen are able to bind to and activate DDR1, which then regulates cell and tissue homeostasis acting as a collagen sensor [21, 54]. Of note, an abnormal expression and deposition of collagen has been associated with cancer development [55-56]. As it concerns the synthesis and extracellular accumulation of diverse types of collagen, cytokines and growth factors like IGF-I, the epidermal growth factor (EGF) and the transforming growth factor- $\beta 1$ have been reported to promote these effects $[38-40,57]$. Notably, we previously showed that, in breast cancer cells, IGF-I may upregulate DDR1 expression through a signaling pathway involving the DDR1 regulatory miR-199a-5p [12]. Moreover, the activation of one of the main IGF-I transduction signaling, the IGF-IR/PI3K/Akt cascade, inhibits miR-199a-5p expression, thus relieving its inhibition upon DDR1 gene and allowing DDR1 upregulation. In turn, DDR1 increases IGF-IR expression through post-transcriptional mechanisms and amplifies IGF-I downstream signaling and biological effects, such as proliferation, migration and colony formation [12]. Indeed, we previously showed that DDR1 directly interacts with IGF-IR, and that this interaction is enhanced by IGF-I stimulation, which promotes rapid DDR1 tyrosine-phosphorylation and cointernalization of the DDR1 - IGF-IR complex [22]. This interaction was shown to occur in a panel of human breast cancer cells as well as in mouse fibroblasts (R-cells) cotransfected with the human IGF-IR and DDR1, indicating that it is not cell-specific. Notably, the formation of this DDR1 - IGF-IR complex did not require the presence of collagen, the canonical DDR1 ligand. In addition, the critical role of IGF-IR in DDR1 activation and biological actions is supported by the finding that collagen-dependent DDR1 phosphorylation was impaired in the absence of IGF-IR [22].

Extending these previous studies, we now show that IGF-I through the cognate receptor IGF-IR is able to induce COL1A1 expression [54]. Moreover, a panel of DDR1 target genes could be also induced by IGF-I through the previously described functional crosstalk involving IGF-IR and DDR1. Taken together, these findings show that DDR1, besides enhancing the activation of typical IGF-IR downstream cascades, the $\mathrm{PI} 3 \mathrm{~K} / \mathrm{Akt}$ and the ERK1/2 cascades, following cell exposure to IGF-I, modifies significantly these IGF-I effects by allowing the induction of typical DDR1 target genes. These effects confirm the relevance of DDR1 in the amplification and diversification of IGF-I signaling pathways in cancer. We have previously demonstrated that IGF-IR may also functionally interact with the noncanonical estrogen receptor GPER. Indeed, through the

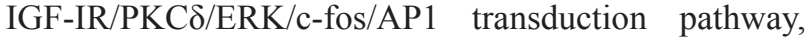
IGF-I up-regulates GPER, which plays an important role in sustaining proliferation and migration in response to IGF-I in breast and endometrial human cancer cells [25]. In close accordance with these findings, we now show that the functional cooperation between IGF-IR and DDR1 also requires GPER, and that both DDR1 and GPER are critical to the chemotactic motility stimulated by IGF-I in mesothelioma and lung cancer cells. Notably, we now show that GPER and IGF-IR co-immunoprecipitate in lung and mesothelioma cells (Figure 2), indicating that GPER and IGF-IR also interact. Taken together all these data strongly suggest the possible formation of a ternary functional complex involving IGF-IR - DDR1 - GPER. However, further studies are needed to fully elucidate this aspect. These data may be of a particular interest as GPER expression has been associated with negative clinical features and poor survival rates in diverse types of malignancies [58-61]. In the last years, extensive studies were therefore performed in order to better characterize the role of GPER in cancer development, including the mechanisms and factors involved in its expression. For instance, we determined that EGF and IGF-I, insulin and further tumorigenic factors like hypoxia and endothelin-1 up-regulate GPER expression in diverse cancer cell contexts [25, 62-68].

Our present findings provide significant new insights on the well-established role played by the IGF axis in cancer $[9-11,14-16,20,23,69-71]$ that involves also the interaction of IGF-IR with other RTKs and GPCRs in diverse tumor histotypes [19, 23, 72-73]. In particular, our findings might be relevant in devising new therapeutical strategies in cancers with a dysregulated IGF system. In the last decade, much effort has been made in targeting the IGF-IR in these malignancies [74]. In particular, both small-molecule IGF-IR tyrosine kinase inhibitors, and humanized monoclonal antibodies with blocking activity to the IGF-IR, have been investigated in Phase III trials of advanced non-small cell lung cancers [13]. Unfortunately, in spite of very promising preclinical studies, clinical trials have clearly indicated that only a small minority of malignancies do respond to target therapies when IGF-IR is the sole target [75], because the frequent occurrence of resistance mechanisms arising by the complex signaling network involving the IGF-IR [76].

Overall, on the basis of our data the multifaceted signaling network between IGF-IR, GPER and DDR1 could be taken into account in setting innovative combined strategies targeting these pathways in mesothelioma and lung cancers. 
$\mathbf{A}$

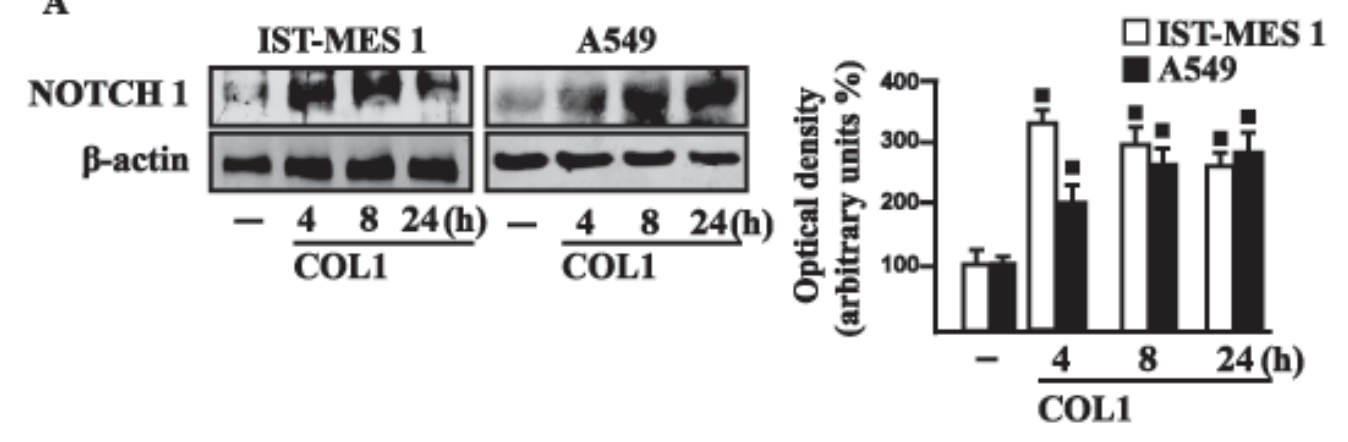

B
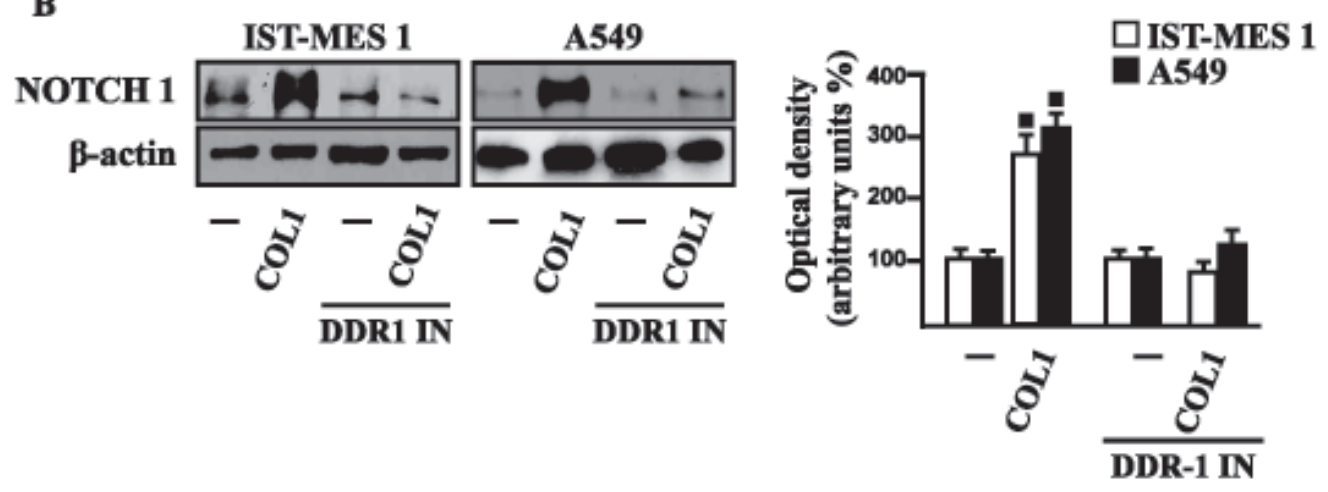

C
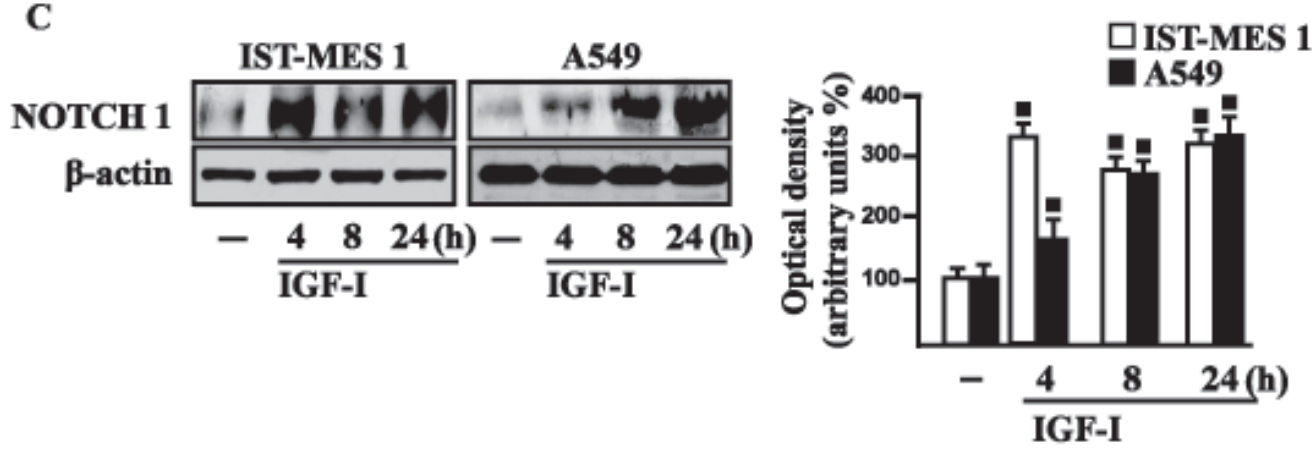

D
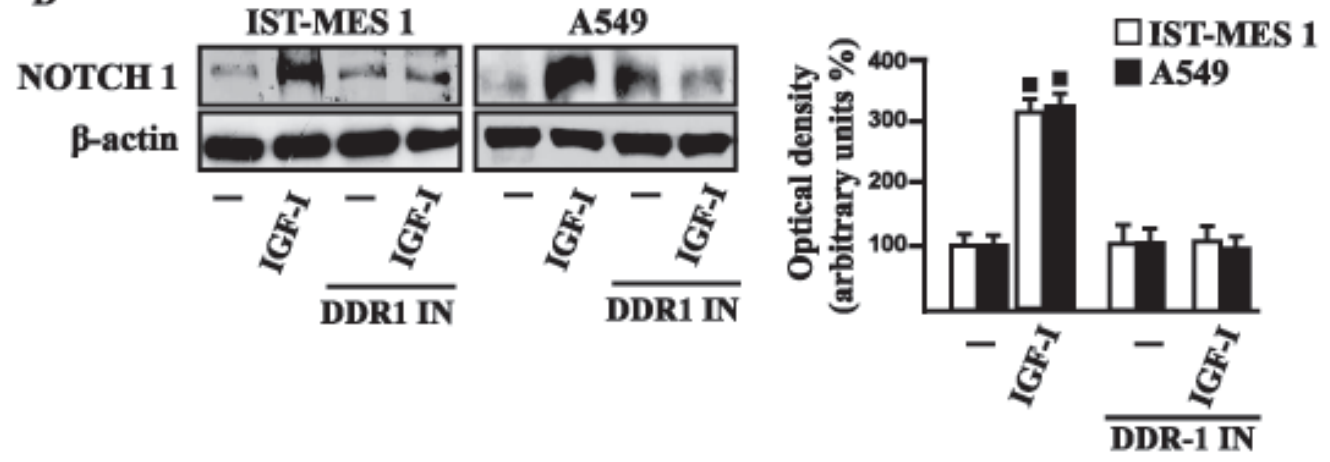

Figure 7: COL1 and IGF-I stimulate NOTCH 1 expression through DDR1 in IST-MES 1 and A549 cells. A. NOTCH 1 protein levels in cells treated with vehicle (-) or $10 \mu \mathrm{g} / \mathrm{ml} \mathrm{COL1}$, as indicated. B. NOTCH 1 protein levels in cells treated for $8 \mathrm{~h}$ with vehicle (-) or $10 \mu \mathrm{g} / \mathrm{ml} \mathrm{COL} 1$ alone and in combination with $1 \mu \mathrm{M}$ DDR1 inhibitor (DDR1 IN). C. NOTCH 1 protein levels in cells treated with vehicle (-) or $100 \mathrm{ng} / \mathrm{ml}$ IGF-I, as indicated. D. NOTCH 1 protein levels in cells treated for $8 \mathrm{~h}$ with vehicle (-) or $100 \mathrm{ng} / \mathrm{ml} \mathrm{IGF-I} \mathrm{alone}$ and in combination with $1 \mu \mathrm{M}$ DDR 1 inhibitor (DDR1 IN). Side panels show densitometric analysis of the blots normalized to $\beta$-actin and each data point represents the mean \pm SD of three independent experiments. (-) $p<0.05$ for cells receiving vehicle (-) versus treatments. 
A
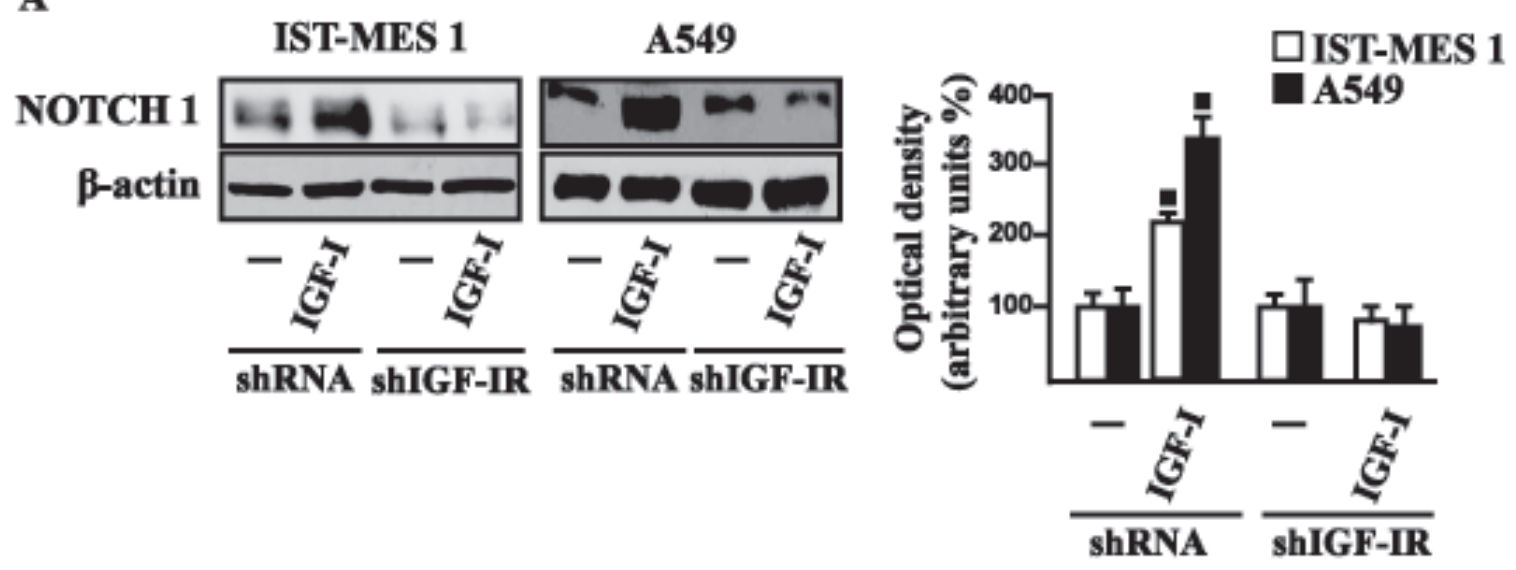

B

C

IST-MES 1

IGF-IR

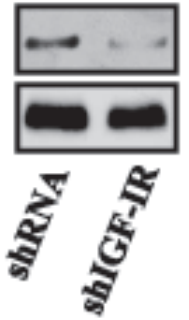

$\mathbf{A 5 4 9}$

p-actin

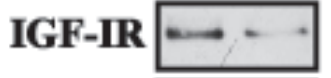

p-actin
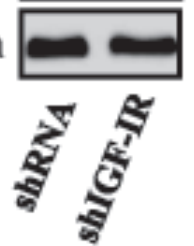

D
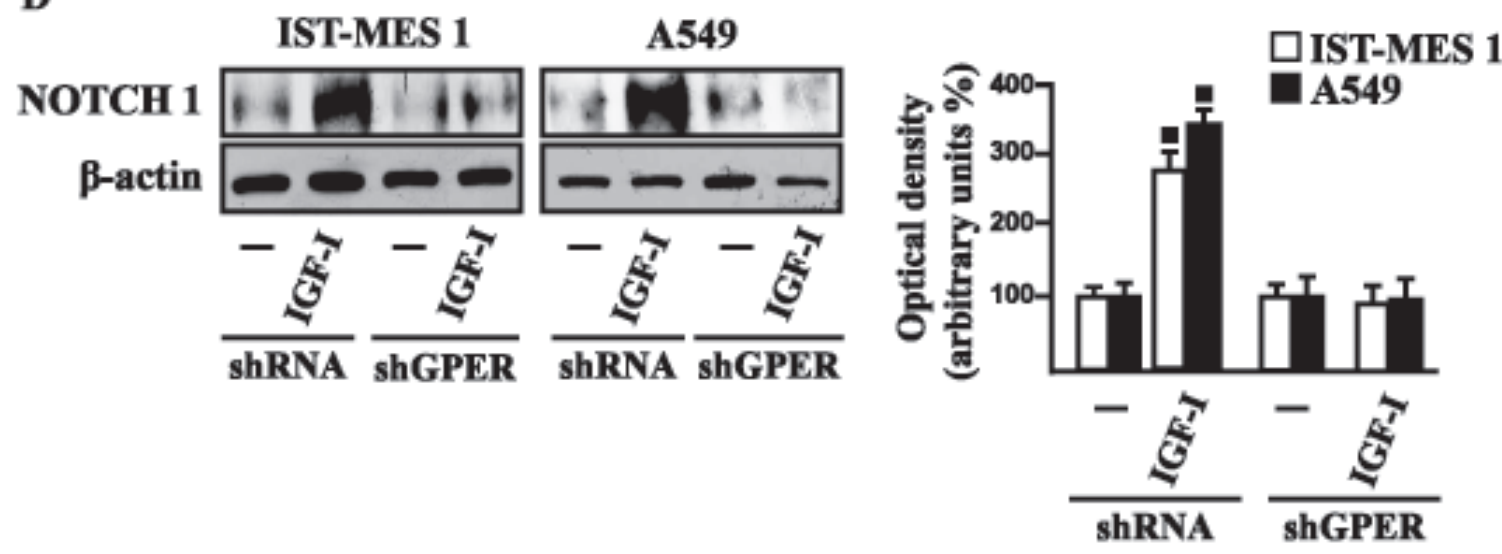

$\mathbf{E}$

F

IST-MES 1

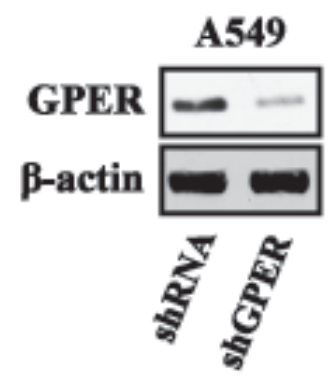

Figure 8: IGF-IR and GPER mediate the IGF-I induced up-regulation of NOTCH 1 in IST-MES 1 and A549 cells. NOTCH 1 protein levels in cells transfected for $24 \mathrm{~h}$ with shIGF-IR A. or shGPER D. and then treated for $8 \mathrm{~h}$ with vehicle (-) or $100 \mathrm{ng} /$ $\mathrm{ml}$ IGF-I. Efficacy of IGF-IR B.-C. and GPER E.-F. silencing. Side panels show densitometric analysis of the blots normalized to $\beta$-actin. (-) $p<0.05$ for cells receiving vehicle (-) versus treatments. 
$\mathbf{A}$

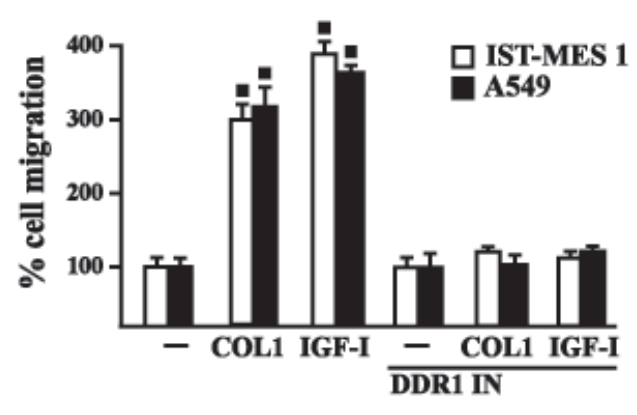

C

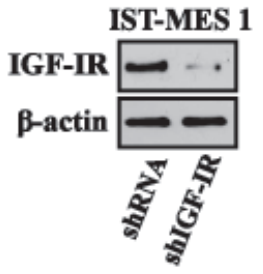

B

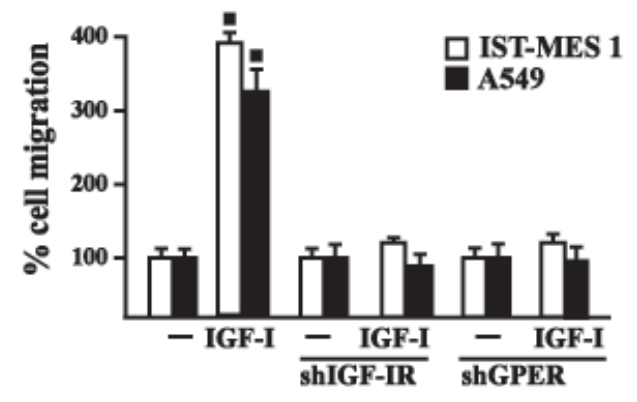

D

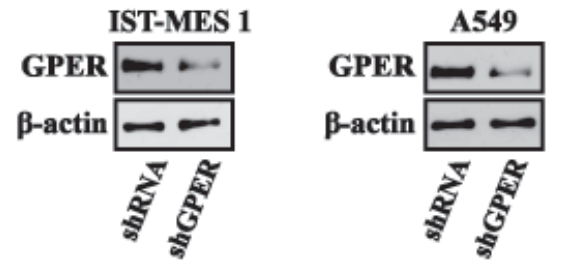

Figure 9: COL1 and IGF-I stimulate IST-MES 1 and A549 cell migration through DDR1, IGF-IR and GPER. A. The migration of IST-MES 1 and A549 cells upon $8 \mathrm{~h}$ treatment with vehicle (-), $10 \mu \mathrm{g} / \mathrm{ml} \mathrm{COL1} \mathrm{or} 100 \mathrm{ng} / \mathrm{ml} \mathrm{IGF-I} \mathrm{alone} \mathrm{and} \mathrm{in} \mathrm{combination}$ with $1 \mu \mathrm{M}$ DDR1 inhibitor (DDR1 IN), as evaluated by Boyden Chamber assay. B. The migration of IST-MES 1 and A549 cells induced by $8 \mathrm{~h}$ treatment with $100 \mathrm{ng} / \mathrm{ml}$ IGF-I was prevented knocking down IGF-IR and GPER expression, as evaluated by Boyden Chamber assay. Efficacy of IGF-IR C.-D. and GPER E.-F. silencing. Values represent the mean \pm SD of three independent experiments. ( $\bullet$ ) indicates $p<$ 0.05 for cells treated with vehicle (-) versus treatments.

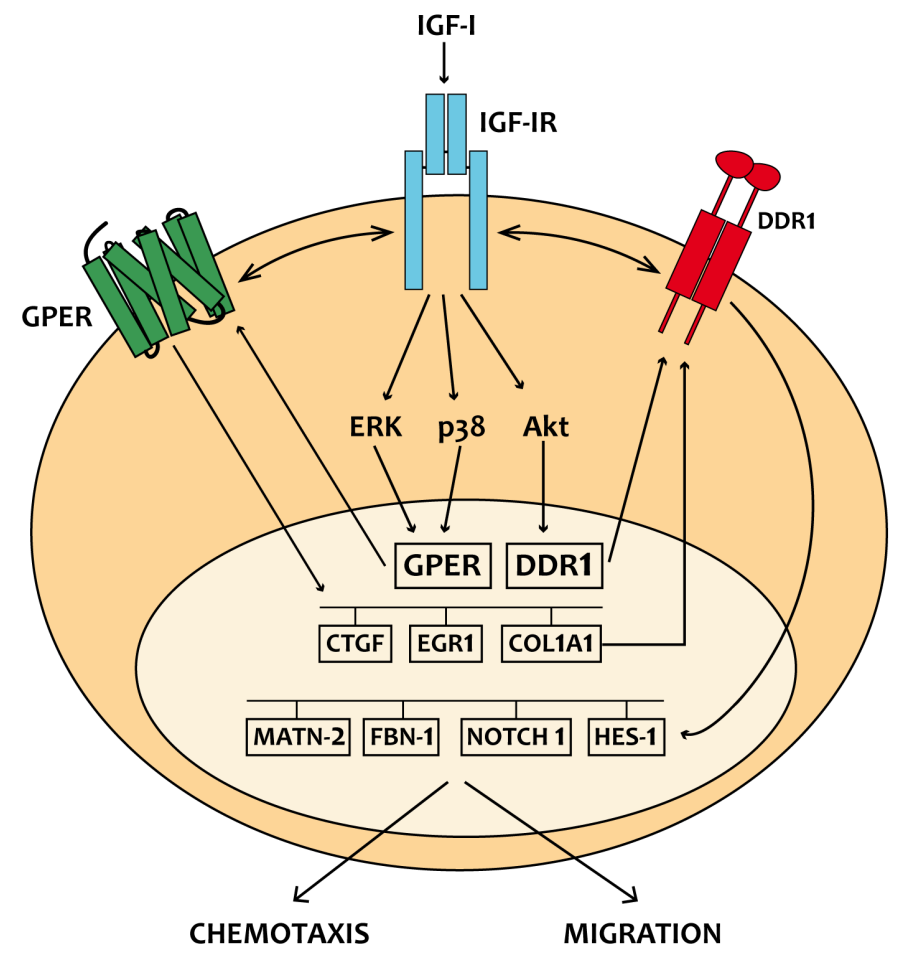

Figure 10: Schematic representation of the signaling network between IGF-IR, GPER and DDR1 activated by IGF-I. IGF-I stimulates the expression of GPER and its target genes, then IGF-IR and GPER trigger the IGF-I regulation of DDR1 target genes. The functional cross-talk of IGF-IR, GPER and DDR1 contributes to the chemotaxis and migration observed in cancer cells. 


\section{MATERIALS AND METHODS}

\section{Reagents}

IGF-I, SB202190 (SB) and collagen I from rat tail were obtained from Sigma-Aldrich Inc. (Milan, Italy). PD98059 (PD) and 3-bromo-5-t-butyl-4hydroxybenzylidenemalonitrile (AG1024) were purchased from Calbiochem (DBA, Milan, Italy). All compounds were solubilized in dimethylsulfoxide, except PD and IGF-I, which were dissolved in ethanol and in water, respectively. DDR1IN1 dihydrochloride (DDR-1 in) was purchased from Tocris Bioscience (Space, Milan, Italy).

\section{Cell cultures}

IST-MES1 malignant mesothelioma cells were kindly provided by Dr. Orengo (Istituto Nazionale per la Ricerca sul Cancro, Genova, Italy). Cells were previously characterized [77] and were grown in Nutrient Mixture F-10 Ham (Ham's F-10) medium supplemented with $10 \%$ fetal bovine serum (FBS) and $100 \mu \mathrm{g} / \mathrm{ml}$ penicillin/ streptomycin. A549 lung cancer cells were obtained by ATCC, used $<6$ months after resuscitation and maintained in DMEM/F12 (Dulbecco's modified Eagle's medium) supplemented with phenol red 10\% FBS and $100 \mu \mathrm{g} / \mathrm{ml}$ penicillin/streptomycin. All cell lines were cultured at $37^{\circ} \mathrm{C}$ in $5 \% \mathrm{CO}_{2}$ and switched to medium without serum the day before immunoblots and reverse transcriptionPCR experiments.

\section{Plasmids and luciferase assays}

The GPER luciferase expression vector (promGPER) was previously described [65]. The CTGF luciferase reporter plasmid (promCTGF) (-1999/+ 36)luc was a gift from Dr. Chaqour. EGR1-luc plasmid, containing the -600 to +125 '-flanking sequence from the human EGR1 gene, was kindly provided by Dr. Safe (Texas A\&M University). The plasmid DN/cfos, which encodes a c-fos mutant that heterodimerizes with c-fos dimerization partners but does not allow DNA biding [78], was a kind gift from Dr C Vinson (NIH, Bethesda, MD, USA). The Renilla luciferase expression vector pRL-TK (Promega, Milan, Italy) was used as internal transfection control. Cells $\left(1 \times 10^{5}\right)$ were plated into $24-$ well dishes with $500 \mu \mathrm{l} /$ well culture medium containing $10 \%$ FBS. Transfection were performed using X-treme GENE 9 DNA transfection reagent as recommended by the manufacturer (Roche Diagnostics, Milan, Italy), with a mixture containing $0.5 \mu \mathrm{g}$ of reporter plasmid and $10 \mathrm{ng}$ of pRL-TK. After $24 \mathrm{~h}$, treatments were added and cells were incubated for $18 \mathrm{~h}$. Luciferase activity was measured using the Dual Luciferase Kit (Promega, Milan, Italy) according to the manufacturer's recommendations. Firefly luciferase activity was normalized to the internal transfection control provided by the Renilla luciferase activity. Normalized relative light unit values obtained from cells treated with vehicle were set as 1-fold induction upon which the activity induced by treatments was calculated.

\section{Gene silencing experiments}

Cells were plated onto $10-\mathrm{cm}$ dishes and transfected by X-treme GENE 9 DNA Transfection Reagent for $24 \mathrm{~h}$ before treatments with a control vector, a specific shRNA sequence for each target gene. The shIGF-IR and the respective control plasmids (shRNA) were purchased from SA Bioscience Corp. (Frederick, MD, USA) and used according to the manufacturer's recommendations. The short hairpin (sh)RNA constructs to knock down the expression of GPER and the unrelated shRNA control construct have been described previously [64].

\section{Gene expression studies}

Total RNA was extracted and cDNA was synthesized by reverse transcription as previously described [79-80]. The expression of selected genes was quantified by realtime PCR using Step One sequence detection system (Applied Biosystems, Milan, Italy). Gene-specific primers were designed using Primer Express version 2.0 software (Applied Biosystems Inc. Milan, Italy) and are as follows: GPER Fwd 5'- ACACACCTGGGTGGACACAA-3' and Rev 5'-GGAGCCAGAAGCCACATCTG-3'; HES1 Fwd 5'-TCAACACGACACCGGATAAA-3' and Rev 5'-CCGCGAGCTATCTTTCTTCA-3'; NOTCH 1 Fwd 5'-AATGGCGGGAAGTGTGAAGC-3' and Rev 5'-GCATAGTCTGCCACGCCTCT-3'; MTN2 Fwd 5'-CTCCGAGTGGGCCAGTAAAG-3' and Rev 5'- CTGGCTCAGATTCTGTTGGCT-3'; FBN1 Fwd 5'-GCCGCATATCTCCTGACCTC-3' and Rev 5'-GTCGATACACGCGGAGATGT-3'; $18 \mathrm{~S}$ Fwd 5'- GGCGTCCCCCAACTTCTTA-3' and Rev 5'-GGGCATCACAGACCTGTTATT-3'. Assays were performed in triplicate and the results were normalized for $18 \mathrm{~S}$ expression and then calculated as fold induction of RNA expression.

\section{Western blot analysis}

Cells were processed according to a previously described protocol [81] to obtain protein lysate that was electrophoresed through a reducing $\operatorname{SDS} / 10 \%(\mathrm{w} / \mathrm{v})$ polyacrylamide gel, electroblotted onto a nitrocellulose membrane and probed with primary antibodies against antiphosphotyrosine antibody (4G10) (Merck Millipore, 
Milan, Italy), IGF-IR (7G11), GPER (N-15), CTGF (L-20), phosphorylated ERK1/2 (E-4), ERK2 (C-14), NOTCH 1 (C-20), EGR1 (588), phosphorylated p-38 (D8), p-38 (A-12), $\beta$-actin (C2), (Santa Cruz Biotechnology, DBA, Milan, Italy). Proteins were detected by horseradish peroxidase-linked secondary antibodies (DBA, Milan, Italy) and revealed using the ECL System (GE Healthcare).

\section{Co-immunoprecipitation}

Cells were lysed using $200 \mu$ l RIPA buffer with a mixture of protease inhibitors containing $1.7 \mathrm{mg} / \mathrm{ml}$ aprotinin, $1 \mathrm{mg} / \mathrm{ml}$ leupeptin, 200mmol/L phenylmethylsulfonyl fluoride, $200 \mathrm{mmol} / \mathrm{L}$ sodium orthovanadate, and $100 \mathrm{mmol} / \mathrm{L}$ sodium fluoride. A total of $100 \mu \mathrm{g}$ proteins were incubated for $2 \mathrm{~h}$ with $2 \mu \mathrm{g}$ of the appropriate antibody (GPER, N-15; IGF-1R, 7G11) and $20 \mu \mathrm{l}$ of protein $\mathrm{A} / \mathrm{G}$ agarose immunopreciptation reagent (Santa Cruz Biotechnology, DBA, Milan, Italy). Samples were centrifuged at $13,000 \mathrm{rpm}$ for $5 \mathrm{~min}$ at $4^{\circ} \mathrm{C}$ to pellet beads. After four washes in PBS, samples were resuspended in RIPA buffer with protease inhibitors and SDS sample buffer. Western Blot analysis was performed as described above.

\section{Migration assay}

Migration assays were performed using Boyden chambers (Costar Transwell, $8 \mathrm{~mm}$ polycarbonate membrane, Sigma Aldrich, Milan, Italy). Cells were transfected in regular growth medium. After $8 \mathrm{~h}$, cells were trypsinized and seeded in the upper chambers. Treatments were added to the medium without serum in the bottom wells where applicable, cells on the bottom side of the membrane were fixed and counted 8 hours after seeding.

\section{Time-lapse microscopy}

Cells $\left(1 \times 10^{5}\right)$ were seeded in 6-well plates and maintained in regular growth medium for $24 \mathrm{~h}$. For knockdown experiments, cells were transfected for $24 \mathrm{~h}$ with shRNA constructs directed against IGFIR or GPER and with an unrelated shRNA construct. Thereafter, cells were treated and transferred into a timelapse microscopy platform, equipped with a heated stage chamber (Cytation ${ }^{\mathrm{TM}} 3$ Cell Imaging Multi-Mode Reader, Biotek, Winooski, VT). Cells were maintained at routine incubation settings $\left(37^{\circ} \mathrm{C}, 5 \% \mathrm{CO}_{2}\right)$ using temperature and gas controllers. To evaluate chemotaxis the images were recorded using Cytation 3 Cell Imaging Multimode Reader and the software Gen5 (BioTek, Winooski, VT) in $10 \mathrm{~min}$ intervals for 8 hours. Then, the images were processed as a movie using the software Adobe Creative Cloud Premier Pro CC. Frames collected every 10 minutes are displayed at a rate of 10 frames s- ${ }^{-1}$.

\section{Statistical analysis}

Statistical analysis was performed using ANOVA followed by Newman-Keuls' testing to determine differences in means. $P<0.05$ was considered as statistically significant.

\section{GRANT SUPPORT}

This work was supported by Associazione Italiana per la Ricerca sul Cancro (MM: IG 16719/2015; AB: IG 14066/2013), Ministero della Salute (grant n. 67/GR2010-2319511); SA was supported by Fellowships INAILRegione Calabria; EMDF was supported by an iCARE fellowship from the Associazione Italiana per la Ricerca sul Cancro (AIRC) cofunded by Marie Curie Actions.

\section{CONFLICTS OF INTEREST}

The authors declare no conflict of interest.

\section{REFERENCES}

1. Travis WD, Brambilla E, Noguchi M, Nicholson AG, Geisinger K, Yatabe Y, Powell CA, Beer D, Riely G, Garg K, Austin JH, Rusch VW, Hirsch FR et al. International Association for the Study of Lung Cancer/ American Thoracic Society/European Respiratory Society: international multidisciplinary classification of lung adenocarcinoma: executive summary. Proc Am Thorac Soc. 2011; 8: 381-5.

2. Guo L, Zhang T, Xiong Y, Yang Y. Roles of NOTCH1 as a Therapeutic Target and a Biomarker for Lung Cancer: Controversies and Perspectives. Dis Markers. 2015; 2015: 520590.

3. Abdel-Rahman O. Targeting the MEK signaling pathway in non-small cell lung cancer (NSCLC) patients with RAS aberrations. Ther Adv Respir Dis. 2016.

4. Silvestri GA, Gonzalez AV, Jantz MA, Margolis ML, Gould MK, Tanoue LT, Harris LJ, Detterbeck FC. Methods for staging non-small cell lung cancer: Diagnosis and management of lung cancer, 3rd ed: American College of Chest Physicians evidence-based clinical practice guidelines. Chest. 2013; 143: e211S-50S.

5. Rajer M, Zwitter M, Rajer B. Pollution in the working place and social status: co-factors in lung cancer carcinogenesis. Lung Cancer. 2014; 85: 346-50.

6. Carbone M, Ly BH, Dodson RF, Pagano I, Morris PT, Dogan UA, Gazdar AF, Pass HI, Yang H. Malignant mesothelioma: facts, myths, and hypotheses. J Cell Physiol. 2012; 227: 44-58. 
7. Rascoe PA, Jupiter D, Cao X, Littlejohn JE, Smythe WR. Molecular pathogenesis of malignant mesothelioma. Expert Rev Mol Med. 2012; 14: e12.

8. Valavanidis A, Vlachogianni T, Fiotakis K, Loridas S. Pulmonary oxidative stress, inflammation and cancer: respirable particulate matter, fibrous dusts and ozone as major causes of lung carcinogenesis through reactive oxygen species mechanisms. Int J Environ Res Public Health. 2013; 10: 3886-907.

9. Belfiore A, Frasca F, Pandini G, Sciacca L, Vigneri R. Insulin receptor isoforms and insulin receptor/insulin-like growth factor receptor hybrids in physiology and disease. Endocr Rev. 2009; 30: 586-623.

10. Belfiore A, Malaguarnera R. Insulin receptor and cancer. Endocr Relat Cancer. 2011; 18: R125-47.

11. Kai K, D'Costa S, Sills RC, Kim Y. Inhibition of the insulin-like growth factor 1 receptor pathway enhances the antitumor effect of cisplatin in human malignant mesothelioma cell lines. Cancer Lett. 2009; 278: 49-55.

12. Matà $\mathrm{R}$, Palladino $\mathrm{C}$, Nicolosi ML, Lo Presti AR, Malaguarnera R, Ragusa M, Sciortino D, Morrione A, Maggiolini M, Vella V, Belfiore A. IGF-I induces upregulation of DDR1 collagen receptor in breast cancer cells by suppressing MIR-199a-5p through the PI3K/AKT pathway. Oncotarget. 2016; 7: 7683-700. doi: 10.18632/ oncotarget.6524.

13. Scagliotti GV and Novello S. The role of the insulin-like growth factor signaling pathway in non-small cell lung cancer and other solid tumors. Cancer Treat Rev. 2012; 38: 292-302.

14. Carboni JM, Lee AV, Hadsell DL, Rowley BR, Lee FY, Bol DK, Camuso AE, Gottardis M, Greer AF, Ho CP, Hurlburt W, Li A, Saulnier M, et al. Tumor development by transgenic expression of a constitutively active insulinlike growth factor I receptor. Cancer Res. 2005; 65: 3781-7.

15. Franks SE, Briah R, Jones RA, Moorehead RA. Unique roles of Akt1 and Akt2 in IGF-IR mediated lung tumorigenesis. Oncotarget. 2016; 7: 3297-316. doi: 10.18632/oncotarget.6489.

16. Hoang CD, Zhang X, Scott PD, Guillaume TJ, Maddaus MA, Yee D, Kratzke RA. Selective activation of insulin receptor substrate-1 and -2 in pleural mesothelioma cells: association with distinct malignant phenotypes. Cancer Res. 2004; 64: 7479-85.

17. Lee H, Kim SR, Oh Y, Cho SH, Schleimer RP, Lee YC. Targeting insulin-like growth factor-I and insulin-like growth factor-binding protein-3 signaling pathways. A novel therapeutic approach for asthma. Am J Respir Cell Mol Biol. 2014; 50: 667-77.

18. Hung CF, Rohani MG, Lee SS, Chen P, Schnapp LM. Role of IGF-1 pathway in lung fibroblast activation. Respir Res. 2013; 14: 102.

19. Lappano R and Maggiolini M. G protein-coupled receptors: novel targets for drug discovery in cancer. Nat Rev Drug Discov. 2011; 10: 47-60.

20. Liu C, Zhang Z, Tang H, Jiang Z, You L, Liao Y1.Crosstalk between IGF-1R and other tumor promoting pathways. Curr Pharm Des. 2014; 20: 2912-21.

21. Valiathan RR, Marco M, Leitinger B, Kleer CG, Fridman R. Discoidin domain receptor tyrosine kinases: new players in cancer progression. Cancer Metastasis Rev. 2012; 31: 295 321.

22. Malaguarnera R, Nicolosi ML, Sacco A, Morcavallo A, Vella V, Voci C, Spatuzza M, Xu SQ, Iozzo RV, Vigneri R, Morrione A, Belfiore A. Novel cross talk between IGFIR and DDR1 regulates IGF-IR trafficking, signaling and biological responses. Oncotarget. 2015; 6: 16084-105. doi: 10.18632/oncotarget.3177.

23. Rozengurt E, Sinnett-Smith J, Kisfalvi K. Crosstalk between insulin/insulin-like growth factor-1 receptors and $\mathrm{G}$ protein-coupled receptor signaling systems: a novel target for the antidiabetic drug metformin in pancreatic cancer. Clin Cancer Res. 2010; 16: 2505-11.

24. Liu C, Liao Y, Fan S, Tang H, Jiang Z, Zhou B, Xiong J, Zhou S, Zou M, Wang J. G protein-coupled estrogen receptor (GPER) mediates NSCLC progression induced by $17 \beta$-estradiol (E2) and selective agonist G1. Med Oncol. 2015; 32: 104.

25. De Marco P, Bartella V, Vivacqua A, Lappano R, Santolla MF, Morcavallo A, Pezzi V, Belfiore A, Maggiolini M. Insulin-like growth factor-I regulates GPER expression and function in cancer cells. Oncogene. 2013; 32: 678-88.

26. De Marco P, Cirillo F, Vivacqua A, Malaguarnera R, Belfiore A, Maggiolini M. Novel Aspects Concerning the Functional Cross-Talk between the Insulin/IGF-I System and Estrogen Signaling in Cancer Cells. Front Endocrinol (Lausanne). 2015; 6: 30.

27. Jala VR, Radde BN, Haribabu B, Klinge CM. Enhanced expression of G-protein coupled estrogen receptor (GPER/ GPR30) in lung cancer. BMC Cancer. 2012; 12: 624.

28. Siegfried JM, Hershberger PA, Stabile LP. Estrogen receptor signaling in lung cancer. Semin Oncol. 2009; 36: 524-31.

29. Pinton G, Brunelli E, Murer B, Puntoni R, Puntoni M, Fennell DA, Gaudino G, Mutti L, Moro L. Estrogen receptor-beta affects the prognosis of human malignant mesothelioma. Cancer Res. 2009; 69: 4598-604.

30. Pillai K, Pourgholami MH, Chua TC, Morris DL. Oestrogen receptors are prognostic factors in malignant peritoneal mesothelioma. J Cancer Res Clin Oncol. 2013; 139: 987-94.

31. Kim, JS, Kim, ES, Liu, D, Lee, JJ, Solis, L, Behrens, C, Lippman, SM, Hong, WK, Wistuba, II, Lee, HY. Prognostic implications of tumoral expression of insulin like growth factors 1 and 2 in patients with non-small-cell lung cancer. Clinical Lung Cancer. 2014; 15: 213-221.

32. Liu Z and Klominek J. Chemotaxis and chemokinesis of 
malignant mesothelioma cells to multiple growth factors. Anticancer Res. 2004; 24: 1625-30.

33. Pandey DP, Lappano R, Albanito L, Madeo A, Maggiolini M, Picard D. Estrogenic GPR30 signalling induces proliferation and migration of breast cancer cells through CTGF. EMBO J. 2009; 28: 523-32.

34. Fujii M, Nakanishi H, Toyoda T, Tanaka I, Kondo Y, Osada $\mathrm{H}$, Sekido $\mathrm{Y}$. Convergent signaling in the regulation of connective tissue growth factor in malignant mesothelioma: TGF $\beta$ signaling and defects in the Hippo signaling cascade. Cell Cycle. 2012; 11: 3373-9.

35. Wang L, Chen Z, Wang Y, Chang D, Su L, Guo Y, Liu C. TR1 promotes cell proliferation and inhibits apoptosis through cyclin A and CTGF regulation in non-small cell lung cancer. Tumour Biol. 2014; 35: 463-8.

36. Shan LN, Song YG, Su D, Liu YL, Shi XB, Lu SJ. Early Growth Response Protein-1 Involves in Transforming Growth factor- $\beta 1$ Induced Epithelial-Mesenchymal Transition and Inhibits Migration of Non-Small-Cell Lung Cancer Cells. Asian Pac J Cancer Prev. 2015; 16: 4137-42.

37. Maggiolini M, Picard D. The unfolding stories of GPR30, a new membrane-bound estrogen receptor. J Endocrinol. 2010; 204: 105-14.

38. Blackstock CD, Higashi Y, Sukhanov S, Shai SY, Stefanovic B, Tabony AM, Yoshida T, Delafontaine P. Insulin-like growth factor-1 increases synthesis of collagen type I via induction of the mRNA-binding protein LARP6 expression and binding to the 5' stem-loop of COL1a1 and COL1a2 mRNA. J Biol Chem 2014; 289: 7264-74.

39. Sukhanov S, Higashi Y, Shai SY, Blackstock C, Galvez S, Vaughn C, Titterington J, Delafontaine P. Differential requirement for nitric oxide in IGF-1-induced antiapoptotic, anti-oxidant and anti-atherosclerotic effects. FEBS Lett. 2011; 585: 3065-72.

40. Sukhanov S, Higashi Y, Shai SY, Vaughn C, Mohler J, Li Y, Song YH, Titterington J, Delafontaine P. IGF-1 reduces inflammatory responses, suppresses oxidative stress, and decreases atherosclerosis progression in ApoE-deficient mice. Arterioscler Thromb Vasc Biol. 2007 Dec; 27: 268490 .

41. Inamori $\mathrm{Y}$, Ota $\mathrm{M}$, Inoko $\mathrm{H}$, Okada E, Nishizaki R, Shiota T, Mok J, Oka A, Ohno S, Mizuki N. The COL1A1 gene and high myopia susceptibility in Japanese. Hum Genet. 2007; 122: 151-7.

42. Wang CZ, Yeh YC, Tang MJ. DDR1/E-cadherin complex regulates the activation of DDR1 and cell spreading. Am J Physiol Cell Physiol. 2009; 297: C419-29.

43. Yeh YC, Wu CC, Wang YK, Tang MJ. DDR1 triggers epithelial cell differentiation by promoting cell adhesion through stabilization of E-cadherin. Mol Biol Cell. 2011; 22: 940-53.

44. Eswaramoorthy R, Wang CK, Chen WC, Tang MJ, Ho ML, Hwang CC, Wang HM, Wang CZ. DDR1 regulates the stabilization of cell surface E-cadherin and E-cadherinmediated cell aggregation. J Cell Physiol. 2010; 224: 38797.

45. Hidalgo-Carcedo C, Hooper S, Chaudhry SI, Williamson P, Harrington K, Leitinger B, Sahai E. Collective cell migration requires suppression of actomyosin at cell-cell contacts mediated by DDR 1 and the cell polarity regulators Par3 and Par6. Nat Cell Biol. 2011; 13:49-58.

46. Ahuja J, Kanne JP, Meyer CA. Occupational lung disease. Semin Roentgenol. 2015; 50: 40-51.

47. Lenters V, Vermeulen R, Dogger S, Stayner L, Portengen L, Burdorf A, Heederik D. A meta-analysis of asbestos and lung cancer: is better quality exposure assessment associated with steeper slopes of the exposure-response relationships? Environ Health Perspect. 2011; 119: 154755.

48. Straif K, Benbrahim-Tallaa L, Baan R, Grosse Y, Secretan B, El Ghissassi F, Bouvard V, Guha N, Freeman C, Galichet L, Cogliano V; WHO International Agency for Research on Cancer Monograph Working Group. A review of human carcinogens_-Part C: metals, arsenic, dusts, and fibres. Lancet Oncol. 2009; 10:453-4.

49. Mossman BT, Lippmann M, Hesterberg TW, Kelsey KT, Barchowsky A, Bonner JC. Pulmonary endpoints (lung carcinomas and asbestosis) following inhalation exposure to asbestos. J Toxicol Environ Health B Crit Rev. 2011; 14: 76-121.

50. Avivi-Green C, Singal M, Vogel WF. Discoidin domain receptor 1-deficient mice are resistant to bleomycin-induced lung fibrosis. Am J Respir Crit Care Med. 2006; 174: 420-7.

51. Lemeer S, Bluwstein A, Wu Z, Leberfinger J, Müller K, Kramer K, Kuster B. Phosphotyrosine mediated protein interactions of the discoidin domain receptor 1 . J Proteomics. 2012; 75: 3465-77.

52. Matsuyama W, Watanabe M, Shirahama Y, Oonakahara K, Higashimoto I, Yoshimura T, et al. Activation of discoidin domain receptor 1 on CD14-positive bronchoalveolar lavage fluid cells induces chemokine production in idiopathic pulmonary fibrosis. J Immunol 2005; 174: 64908.

53. Heinzelmann-Schwarz VA, Gardiner-Garden M, Henshall SM, Scurry J, Scolyer RA, Davies MJ, Heinzelmann M, Kalish LH, Bali A, Kench JG, et al. Overexpression of the cell adhesion molecules DDR1, Claudin 3, and Ep-CAM in metaplastic ovarian epithelium and ovarian cancer. Clin Cancer Res 2004; 10: 4427-4436.

54. Vogel WF, Abdulhussein R, Ford CE. Sensing extracellular matrix: an update on discoidin domain receptor function. Cell Signal. 2006; 18: 1108-16.

55. Tavazoie SF, Alarcón C, Oskarsson T, Padua D, Wang Q, Bos PD, Gerald WL, Massagué J. Endogenous human microRNAs that suppress breast cancer metastasis. Nature. 2008; 451: 147-52. 
56. Ramaswamy S, Ross KN, Lander ES, Golub TR. A molecular signature of metastasis in primary solid tumors. Nat Genet. 2003; 33: 49-54.

57. Grande JP, Melder DC, Zinsmeister AR. Modulation of collagen gene expression by cytokines: stimulatory effect of transforming growth factor-beta1, with divergent effects of epidermal growth factor and tumor necrosis factor-alpha on collagen type I and collagen type IV. J Lab Clin Med. 1997; 130: 476-86.

58. Filardo EJ, Graeber CT, Quinn JA, Resnick MB, Giri D, DeLellis RA, Steinhoff MM, Sabo E. Distribution of GPR30, a seven membrane-spanning estrogen receptor, in primary breast cancer and its association with clinicopathologic determinants of tumor progression. Clin Cancer Res. 2006; 12: 6359-66.

59. Smith HO, Arias-Pulido H, Kuo DY, Howard T, Qualls CR, Lee SJ, Verschraegen CF, Hathaway HJ, Joste NE, Prossnitz ER. GPR30 predicts poor survival for ovarian cancer. Gynecol Oncol. 2009; 114: 465-71.

60. Smith HO, Leslie KK, Singh M, Qualls CR, Revankar CM, Joste NE, Prossnitz ER. GPR30: a novel indicator of poor survival for endometrial carcinoma. Am J Obstet Gynecol. 2007; 196: 386.e1-11.

61. Marjon NA, Hu C, Hathaway HJ, Prossnitz ER. G protein-coupled estrogen receptor regulates mammary tumorigenesis and metastasis. Mol Cancer Res. 2014; 12: 1644-54.

62. De Marco P, Romeo E, Vivacqua A, Malaguarnera R, Abonante S, Romeo F, Pezzi V, Belfiore A, Maggiolini M. GPER1 is regulated by insulin in cancer cells and cancerassociated fibroblasts. Endocr Relat Cancer. 2014; 21:73953.

63. Vivacqua A, Lappano R, De Marco P, Sisci D, Aquila S, De Amicis F, Fuqua SA, Andò S, Maggiolini M. G proteincoupled receptor 30 expression is up-regulated by EGF and TGF alpha in estrogen receptor alpha-positive cancer cells. Mol Endocrinol. 2009; 23: 1815-26.

64. Albanito L, Sisci D, Aquila S, Brunelli E, Vivacqua A, Madeo A, Lappano R, Pandey DP, Picard D, Mauro L, Andò S, Maggiolini M. Epidermal growth factor induces $G$ protein-coupled receptor 30 expression in estrogen receptornegative breast cancer cells. Endocrinology. 2008; 149: 3799-808.

65. Recchia AG, De Francesco EM, Vivacqua A, Sisci $\mathrm{D}$, Panno ML, Andò S, Maggiolini M. The G proteincoupled receptor 30 is up-regulated by hypoxia-inducible factor-1alpha (HIF-1alpha) in breast cancer cells and cardiomyocytes. J Biol Chem. 2011; 286: 10773-82.

66. De Francesco EM, Lappano R, Santolla MF, Marsico S, Caruso A, Maggiolini M. HIF-1 $\alpha /$ GPER signaling mediates the expression of VEGF induced by hypoxia in breast cancer associated fibroblasts (CAFs). Breast Cancer Res. 2013; 15: R64.
67. De Francesco EM, Pellegrino M, Santolla MF, Lappano R, Ricchio E, Abonante S, Maggiolini M. GPER mediates activation of HIF $1 \alpha /$ VEGF signaling by estrogens. Cancer Res. 2014; 74: 4053-64.

68. Bartella V, De Francesco EM, Perri MG, Curcio R, Dolce $\mathrm{V}$, Maggiolini M, Vivacqua A. The G protein estrogen receptor (GPER) is regulated by endothelin-1 mediated signaling in cancer cells. Cell Signal. 2016; 28: 61-71.

69. Baserga R, Peruzzi F, Reiss K. The IGF-1 receptor in cancer biology. Int J Cancer. 2003; 107: 873-7.

70. Yakar S, Leroith D, Brodt P. The role of the growth hormone/insulin-like growth factor axis in tumor growth and progression: Lessons from animal models. Cytokine Growth Factor Rev. 2005; 16: 407-420.

71. Novosyadlyy R, Lann DE, Vijayakumar A, Rowzee A, Lazzarino DA, Fierz Y, et al. Insulin-mediated acceleration of breast cancer development and progression in a nonobese model of type 2 diabetes. Cancer Res. 2010; 70: 741-751.

72. Kisfalvi K, Eibl G, Sinnett-Smith J, Rozengurt E. Metformin disrupts crosstalk between $\mathrm{G}$ protein-coupled receptor and insulin receptor signaling systems and inhibits pancreatic cancer growth. Cancer Res. 2009; 69: 6539-45.

73. Akekawatchai C, Holland JD, Kochetkova M, Wallace JC, McColl SR. Transactivation of CXCR4 by the insulin-like growth factor-1 receptor (IGF-1R) in human MDA-MB-231 breast cancer epithelial cells. J Biol Chem. 2005; 280: 39701-8.

74. Gombos A, Metzger-Filho O, Dal Lago L, Awada-Hussein A. Clinical development of insulin-like growth factor receptor-1 (IGF-1R) inhibitors: at the crossroad? Invest New Drugs. 2012; 30: 2433-42.

75. Fidler MJ, Shersher DD, Borgia JA, Bonomi P. Targeting the insulin-like growth factor receptor pathway in lung cancer: problems and pitfalls. Ther Adv Med Oncol. 2012; 4: 51-60.

76. Scotlandi $\mathrm{K}$ and Belfiore A. Targeting the Insulin-Like Growth Factor (IGF) System Is Not as Simple as Just Targeting the Type 1 IGF Receptor. Am Soc Clin Oncol Educ Book. 2012: 599-604.

77. Orengo AM, Spoletini L, Procopio A, Favoni RE, De Cupis A, Ardizzoni A, Castagneto B, Ribotta M, Betta PG, Ferrini S, Mutti L. Establishment of four new mesothelioma cell lines: characterization by ultrastructural and immunophenotypic analysis. Eur Respir J. 1999; 13: 527-34.

78. Gerdes MJ, Myakishev M, Frost NA, Rishi V, Moitra J, Acharya A, Levy MR, Park SW, Glick A, Yuspa SH, Vinson C. Activator protein-1 activity regulates epithelial tumor cell identity. Cancer Res 2006; 66: 7578-7588.

79. Rigiracciolo DC, Scarpelli A, Lappano R, Pisano A, Santolla MF, De Marco P, Cirillo F, Cappello AR, Dolce V, Belfiore A, Maggiolini M, De Francesco EM. Copper activates HIF-1 $\alpha /$ GPER/VEGF signalling in cancer 
cells. Oncotarget. 2015; 6: 34158-77. doi: 10.18632/ oncotarget.5779.

80. Rigiracciolo DC, Scarpelli A, Lappano R, Pisano A, Santolla MF, Avino S, De Marco P, Bussolati B, Maggiolini M, De Francesco EM. GPER is involved in the stimulatory effects of aldosterone in breast cancer cells and breast tumor-derived endothelial cells. Oncotarget. 2016; 7: 94111. doi: 10.18632/oncotarget.6475.
81. De Marco P, Lappano R, De Francesco EM, Cirillo F, Pupo M, Avino S, Vivacqua A, Abonante S, Picard D, Maggiolini M. GPER signalling in both cancer-associated fibroblasts and breast cancer cells mediates a feedforward IL1 $\beta /$ IL1R1 response. Scientific Reports 2016, in press. 